\title{
Simultaneous exposure to vinylcyclohexene and methylmercury in Drosophila melanogaster: biochemical and molecular analyses
}

Bruna Candia Piccoli', Ana Lúcia Anversa Segatto ${ }^{1}$, Cláudia Sirlene Oliveira ${ }^{1,2,3}$, Fernanda D'Avila da Silva ${ }^{1}$, Michael Aschner ${ }^{4}$ and João Batista Teixeira da Rocha ${ }^{1 *}$

From 2nd Latin American Congress of Clinical and Laboratorial Toxicology

Porto Alegre, Brazil. 3-6 June 2018

\begin{abstract}
Background: Exposure to vinylcyclohexene $(\mathrm{VCH})$ and methylmercury $\left(\mathrm{MeHg}^{+}\right)$can induce oxidative stress and gene modulation. Several studies have been evaluating the effects of $\mathrm{VCH}$ and $\mathrm{MeHg}^{+}$, but little is known about interactive effects between them. This work aimed to assess the exposure and co-exposure effects of $\mathrm{MeHg}^{+}$and VCH on oxidative stress and gene modulation in Drosophila melanogaster.
\end{abstract}

Methods: Reactive species production, glutathione S-transferase (GST) and acetylcholinesterase (AChE) activities were evaluated after exposure and co-exposure to $\mathrm{VCH}(1 \mathrm{mM})$ and $\mathrm{MeHg}^{+}(0.2 \mathrm{mM})$ for one or three days in the head and body (thorax and abdomen) of flies. The expression of genes related to redox state and inflammatory response was evaluated after exposure and co-exposure to $\mathrm{VCH}$ and $\mathrm{MeHg}^{+}$for three days.

Results: Survival decreased only in flies co-exposed to $\mathrm{VCH}$ and $\mathrm{MeHg}^{+}$for three days. All treatments increased total reactive species production after one day of exposure. However, no significant changes were observed in the head after three days of exposure. One day of exposure to VCH caused an increase in the head GST activity, whereas $\mathrm{MeHg}^{+}$induced an increase after three days of exposure. Regarding the body, all treatments increased GST activity after one day of exposure, but only the flies exposed to $\mathrm{MeHg}^{+}$presented an increase in GST activity after three days of exposure. Treatments did not alter AChE activity in the head. As for gene expression, there was a significant increase in the Relish transcription factor gene in the flies' body, but Nrf2, Keap1, Jafrac1, TrxR1, and NF$\kappa \beta$ were not altered.

Conclusion: The results suggest that exposure to $\mathrm{VCH}$ and $\mathrm{MeHg}^{+}$induce oxidative stress and activation of an inflammatory response in fruit flies.

Keywords: Oxidative stress, Inflammatory response, Xenobiotic, Alternative model, Drosophila melanogaster

\footnotetext{
* Correspondence: jbtrocha@yahoo.com.br

${ }^{1}$ Departamento de Bioquímica e Biologia Molecular, Centro de Ciências

Naturais e Exatas, Universidade Federal de Santa Maria, Santa Maria, RS, Brazil

Full list of author information is available at the end of the article
}

(c) The Author(s). 2019 Open Access This article is distributed under the terms of the Creative Commons Attribution 4.0 International License (http://creativecommons.org/licenses/by/4.0/), which permits unrestricted use, distribution, and reproduction in any medium, provided you give appropriate credit to the original author(s) and the source, provide a link to the Creative Commons license, and indicate if changes were made. The Creative Commons Public Domain Dedication waiver (http://creativecommons.org/publicdomain/zero/1.0/) applies to the data made available in this article, unless otherwise stated. 


\section{Background}

The toxicity of environmentally relevant contaminants has been commonly determined individually. However, in "real life scenarios" the population is exposed simultaneously to more than one xenobiotic $[1,2]$. Toxicants are widely distributed in the environment, and those found at high levels are mostly associated with anthropogenic activities $[1,3]$. The plastic derivative vinylcyclohexene (VCH) and the ubiquitous metal, mercury $(\mathrm{Hg})$ are examples of environmental contaminants.

$\mathrm{VCH}$ is used commercially as an epoxy resin diluent used in the production of plastic, rubber, and pesticides [4]. Of particular environmental and toxicological concerns, $\mathrm{VCH}$ is found at high concentrations in wastewater derived from the production of hydroxylated liquid polybutadiene [5]. $\mathrm{VCH}$ exposure may occur through inhalation, ingestion, or dermal contact $[6,7]$. Once in the body, $\mathrm{VCH}$ can be oxidized by cytochromes P450, and its double bonds are transformed into epoxy groups [8]. The liver has two cytochromes $\mathrm{P} 450$ isoforms, $2 \mathrm{~A}$ and $2 \mathrm{~B}$, which bioactivate $\mathrm{VCH}$ into its mono (4-vinylcyclohexene 1,2 epoxide or 4vinylcyclohexene 7,8 epoxide) and diepoxide (VCD - 4vinylcyclohexene diepoxide) metabolites, respectively [9]. Also, the ovaries have a cytochrome P450 isoform, 2E1, which oxidizes the two double bonds, forming the diepoxide metabolite [10]. Due to the electrophilicity of the epoxide groups, they have an affinity for nucleophilic centers, such as thiol groups $[11,12]$. Therefore, thiol-containing proteins can be targeted by epoxides in cells representing one of the mechanisms of $\mathrm{VCH}$ metabolites toxicity. In rodents, $\mathrm{VCH}$ and its metabolites have been associated mainly with ovarian damage characterized by the death of primary and primordial follicles [13-15]. Besides, exposure to $\mathrm{VCH}$ or its epoxides has been shown to cause toxic effects in various organs in rodents [15-19].

Another xenobiotic is mercury $(\mathrm{Hg})$, a highly toxic metal and important environmental contaminant that has no function in living organisms [20-22]. Contamination by $\mathrm{Hg}$ has increased due to anthropogenic activities [23]. Among the chemical forms of mercury, the major health concerns are related to the organic forms, i.e., methylmercury $\left(\mathrm{MeHg}^{+}\right) . \mathrm{MeHg}^{+}$is found in the aquatic environment as a product of $\mathrm{Hg}^{2+}$ methylation by microorganisms [24], once formed $\mathrm{MeHg}^{+}$bioaccumulates in the food chain [25-28]. Consequently, the consumption of piscivorous fish by humans is of concern since they are a relevant source of $\mathrm{MeHg}^{+}$[20-22, 29, 30]. Since $\mathrm{MeHg}^{+}$is a soft electrophile, it has a high affinity for soft nucleophiles, i.e., thiol [31-33] and selenol groups, which can be found in proteins [34, 35]. Moreover, thiol groups are found in low molecular mass molecules, such as reduced glutathione (GSH) and cysteine. The affinity of $\mathrm{MeHg}^{+}$for thiol groups is extremely high, and practically no free $\mathrm{MeHg}^{+}$is found in living cells. Indeed, $\mathrm{MeHg}^{+}$in the biological medium is bound to cysteine, GSH, or target proteins. In mammals, $\mathrm{MeHg}^{+}$is transported bound to cysteine or GSH [36, 37]. Glutathione S-transferases (GSTs) are a family of detoxifying enzymes. GSTs catalyze the conjugation of GSH with electrophilic compounds to be neutralized, transported, and eliminated. Several studies have established the involvement of GST in the conjugation of GSH with $\mathrm{MeHg}^{+}[33,38]$ and VCD [39-41].

The use of Drosophila melanogaster in toxicological studies has increased [42-52] given the genome of flies has homology to the human genome [53], thus making it a highly predictive model of toxicity in vertebrates. D. melanogaster has numerous thiol-containing proteins involved in redox signaling [54] and five selenoproteins [55-59]. One of these selenoproteins is selenophosphate synthetase [55], which catalyzes the synthesis of monoselenophosphate. The other four identified selenoproteins are glycine-rich selenoprotein (SelG) [56], selenoprotein birthday (Bthd) [57], ring canal kelch protein (Kel) [58], and glucose dehydrogenase (Gld) [59]. Thus, the toxicity of $\mathrm{VCH}$ and $\mathrm{MeHg}^{+}$in D. melanogaster may be secondary to the inactivation of thioland/or selenol-containing proteins.

The majority of the toxicological studies investigate the isolate toxicity of a given contaminant [14, 60-63]. Studies comparing the effect of exposure to two or more toxicants are timely and meritorious as to characterize potential interactions between environmental contaminants. Here, we hypothesize that co-exposure to $\mathrm{MeHg}^{+}$ and $\mathrm{VCH}$ may have an overlapping mechanism of toxicity via thiol oxidation. Consequently, $\mathrm{MeHg}^{+}$and $\mathrm{VCH}$ coexposure may cause synergistic or additive effects. Accordingly, we used D. melanogaster as a model to study the potential toxicological interactions between $\mathrm{VCH}$ and $\mathrm{MeHg}^{+}$. Markers of electrophilic toxicity, such as reactive species production, GST, and acetylcholinesterase (AChE) activity were determined after exposure and coexposure to $\mathrm{VCH}$ and $\mathrm{MeHg}^{+}$for one or three days. Furthermore, we have also assessed the expression of genes related to oxidative stress and found that some of them were modulated after $\mathrm{VCH}$ and $\mathrm{MeHg}^{+}$co-exposure.

\section{Methods \\ Chemicals}

All chemicals were of analytical grade. 4-vinylcyclohexene (99\%), methylmercury chloride, 1-chloro-2,4-dinitrobenzene (CDNB), 5,5'-dithiobis (2-nitro-benzoic acid) (DTNB), acetylthiocholine iodide, and 2,7-dichlorofluorescein diacetate (DCFDA) were purchased from Sigma Aldrich (St. Louis, MO, USA).

\section{Stock and culture}

Flies (D. melanogaster) were produced by the Toxicological Biochemistry Laboratory of the Universidade Federal de 
Santa Maria (UFSM), Brazil. Stocks were maintained and reared into a medium composed of cornmeal (1\%), sucrose $(1 \%)$, powdered milk (1\%), agar (1\%), yeast extract (2\%), and nipagin $(0.08 \%)$, mixed and cooked with distilled water (200 $\mathrm{mL})$. Temperature and relative humidity were constant at $23{ }^{\circ} \mathrm{C}$ and $60 \%$, respectively, under $12 \mathrm{~h}$ dark/light cycle conditions.

\section{Concentration curves of $\mathrm{MeHg}^{+}$and VCH toxicity}

To determine the concentration to be used in the coexposure treatment, 30 flies (both gender), three-daysold, were exposed to different concentrations of $\mathrm{MeHg}^{+}(0,0.1,0.2$, and $0.4 \mathrm{mM})$ diluted in ethanol $(0.1 \%)$. The experimental procedure consisted of three independent replicates for each concentration tested. The number of dead flies was registered daily for four days (Fig. 1a). The highest concentration of $\mathrm{MeHg}^{+}$ that did not alter flies' survival $(0.2 \mathrm{mM})$ was selected to study the coexposure with $\mathrm{VCH}$. The $\mathrm{VCH}$ concentration was selected based on the study performed by Abolaji et al. [44], where $1 \mathrm{mM}$ was the highest concentration of $\mathrm{VCH}$ that did not alter the flies' survival after five days of exposure.

\section{Co-exposure to $\mathrm{VCH}$ and $\mathrm{MeHg}^{+}$}

The control group was raised in medium containing ethanol $(0.1 \%), \mathrm{VCH}$ group in $1 \mathrm{mmol} \mathrm{VCH} / \mathrm{L}$ of fly food, $\mathrm{MeHg}^{+}$group in $0.2 \mathrm{mmol} \mathrm{MeHg}^{+} / \mathrm{L}$ of fly food and $\mathrm{VCH}+\mathrm{MeHg}^{+}$group in $1 \mathrm{mmol} \mathrm{VCH} / \mathrm{L}+0.2$ $\mathrm{mmol} \mathrm{MeHg}^{+} / \mathrm{L}$ of fly food. Because of the strong affinity of $\mathrm{MeHg}^{+}$for thiol groups [34, 37] it is expected that the $\mathrm{MeHg}^{+}$will react to the thiolcontaining proteins of the diet, mainly the yeast proteins (data are not shown), forming an R-S-HgMe complex $(\mathrm{R}=$ protein $)$, which mimics the intake of this compound by vertebrates [64-68]. In fact, the $\mathrm{MeHg}^{+}$ in fish muscle is found almost exclusively bound to cysteinyl residues of proteins [66]. We also speculated that $\mathrm{MeHg}^{+}$did not interact with the $\mathrm{VCH}$ in the medium because it was associated with food protein. Thirty three-days-old flies were placed into the vials containing the experimental medium and treated for one or three days. At the end of exposure periods (one or three days), flies had four and six-days-old, respectively. The number of dead flies was registered every day. Each experimental procedure consisted of twelve independent replicates.

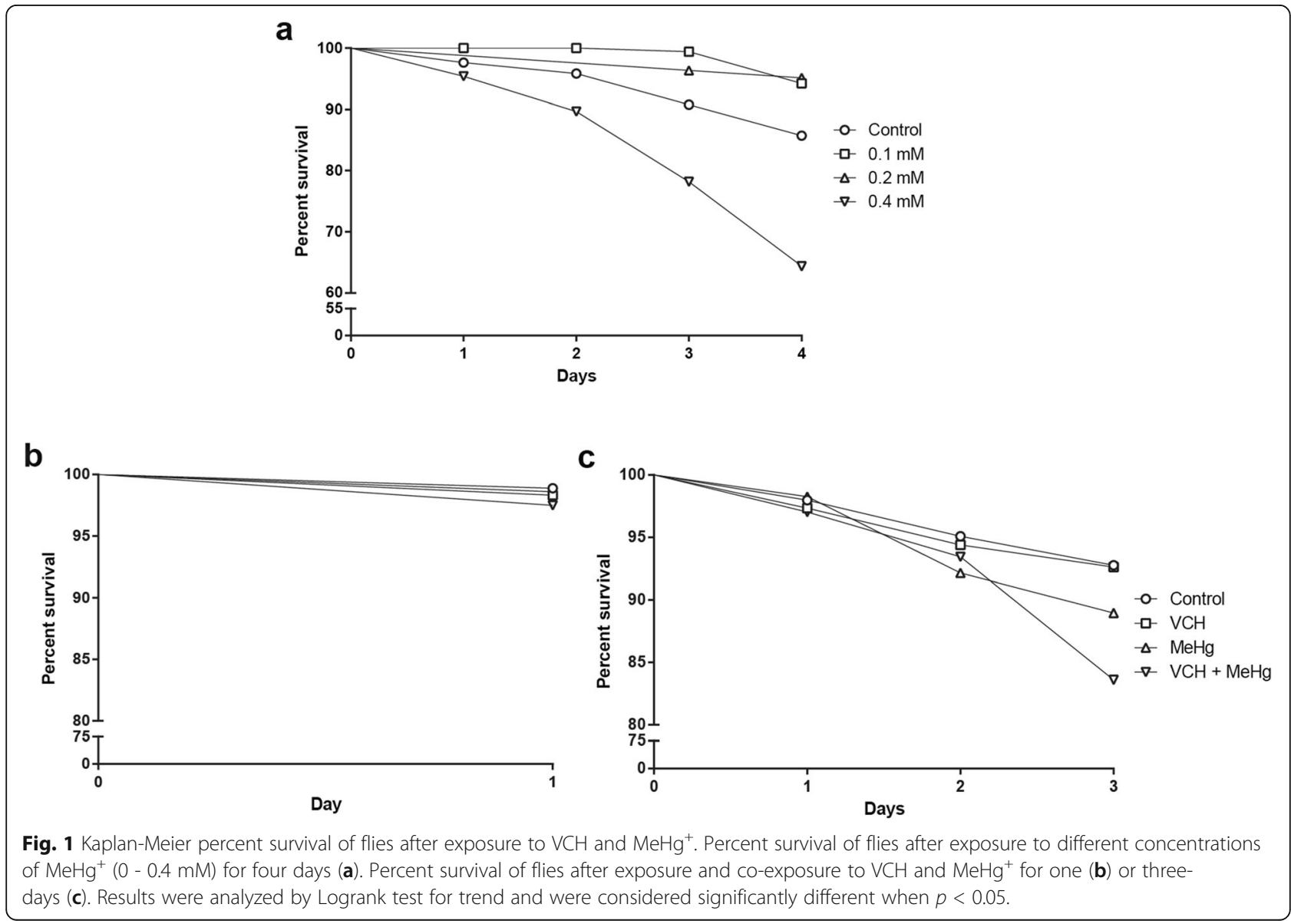




\section{Negative geotaxis}

The negative geotaxis assay was carried out to determine the locomotor performance of flies after exposure and co-exposure to $\mathrm{VCH}$ and $\mathrm{MeHg}^{+}$for one or three days. For this assay, ten flies from each group were cryoanesthetized and placed in vertical glass columns with 15 $\mathrm{cm}$ of length and $1.5 \mathrm{~cm}$ of diameter with a marking at the 6 th $\mathrm{cm}$. After $20 \mathrm{~min}$ (recovery from ice exposure), the flies were tapped to the bottom of the column by a gentle beat, and after $6 \mathrm{~s}$, the number of flies that climbed up the mark was recorded. This assay was independently performed twelve times for each treatment. The number of flies at the top in each replicate was expressed as a percentage of the total number of flies.

\section{Biochemical analyses} Preparation of samples

At the end of the treatments, twenty flies were cryoanesthetized, and their heads were separated from the thorax and abdomen (hereafter named as the body). Heads and bodies were homogenized with $200 \mu \mathrm{L}$ of $100 \mathrm{mM}$ potassium phosphate buffer $\mathrm{pH} 7.4$ and centrifuged at $13,000 \mathrm{rpm}$ for $10 \mathrm{~min}$ at $4{ }^{\circ} \mathrm{C}$. Subsequently, the supernatant was separated from the pellet, and the concentration of protein was determined in the spectrometer Spectra Max at $280 \mathrm{~nm}$. The protein concentration was adjusted to $0.4 \mathrm{mg} / \mathrm{mL}$ for head and $0.3 \mathrm{mg} /$ $\mathrm{mL}$ for body samples. The samples were used for the determination of AChE and GST activities, and reactive species (both oxygen and nitrogen) production. AChE levels in the body were below the level of detection.

\section{Assessment of dichlorofluorescein diacetate oxidation}

The DCFDA assay, which is a general index of oxidative stress, was determined as described by Pérez-Severiano et al. [69]. Briefly, potassium phosphate buffer pH 7.4 $(75 \mathrm{mM})$ and DCFDA $(5 \mu \mathrm{M})$ were mixed with $5 \mu \mathrm{L}$ of sample, and the fluorescence was monitored using a spectrophotometer Spectra Max plate reader, at 488/ $525 \mathrm{~nm}$ of excitation and emission for $25 \mathrm{~min}$ with an interval of $30 \mathrm{~s}$. Results were expressed as the mean of fluorescence intensity unit per minute.

\section{Determination of glutatione S-transferase activity}

GST activity was determined according to Habig et al. [70]. The system consisted of potassium phosphate buffer $\mathrm{pH}$ 7.4 (70 mM), ethylenediaminetetraacetic acid (1 $\mathrm{mM})$, GSH $(3.20 \mathrm{mM})$, and $100 \mu \mathrm{L}$ of sample; then the reaction was started by adding CDNB $(0.80 \mathrm{mM})$. The reaction was monitored using a spectrophotometer Spectra Max plate reader, at $340 \mathrm{~nm}$ for $25 \mathrm{~min}$ with an interval of $30 \mathrm{~s}$. Results were expressed as the mean of absorbance of GSH-CDNB conjugate per minute.

\section{Determination of acetylcholinesterase activity}

AChE activity was determined according to Ellman et al. [71]. The system consisted of potassium phosphate buffer pH 7.4 (10 mM), DTNB $(1 \mathrm{mM})$, acetylthiocholine $(0.8 \mathrm{mM})$, and $30 \mu \mathrm{L}$ of sample. The activity was monitored at $412 \mathrm{~nm}$ for $10 \mathrm{~min}$ with an interval of $2 \mathrm{~min}$. Results were expressed as the mean of acetylthiocholine hydrolyzed in nmol per mg protein per minute.

\section{RNA extraction and reverse transcription-quantitative polymerase chain reaction (RT-qPCR)}

Total RNA was extracted from ten heads or bodies of flies using Trizol ${ }^{\circ}$ according to the manufacturer's protocol. RNA present in the samples was quantified in Nanodrop2000 ${ }^{\text {max }}$ and visualized in $1.5 \%$ agarose gel. RNA $(1 \mu \mathrm{g})$ was treated with DNase I (Invitrogen) according to the manufacturer's specifications. cDNA was synthesized using iScript $^{\text {tax }}$ cDNA Synthesis kit according to the manufacturer's protocol. The amount of RNA was quantified in Nanodrop $2000^{\mathrm{mix}}$, and $2.5 \mathrm{ng} / \mu \mathrm{L}$ was used in RT-qPCR. The primer sequences used in this study were Nuclear factorerythroid 2-related factor 2 (Nrf2), Kelch-like erythroid cell-derived associated protein 1 (Keap1), Nuclear factor- $\kappa B$ (NF-kB) activating protein-like, Jafrac1, thioredoxin reductase (TrxR1), and Relish (Table 1). All expression levels were standardized to two reference genes ( $\beta$-tubulin and glycerol 3-phosphate dehydrogenase (GPDH)) [43].

Table 1 Sequence of RT-qPCR primers.

\begin{tabular}{llll}
\hline Gene & Left & Right & Flybase gene ID \\
\hline Nrf2 (cap-n-collar) & AGCGCATCTCGAACAAGTT & CGTGTTGTACCCTCGGACT & FBgn0262975 \\
Keap1 & CCAACTTCCTCAAGGAGCAG & CGGCGACAAATATCATCCT & FBgn0038475 \\
NF-kB activating protein-like & CCGCAGAAACCAGAGAGTC & TGTGCTTTCTCTTGCCCTT & FBgn0039488 \\
Jafrac1 & TGGATCAACACGCCAAGGAA & GGATGCCAGTCTCCTCATCG & FBgn0040309 \\
TrxR1 & CGTTCTATTGTGCTGCGTGG & AGCTTGCCATCATCCTGCTT & FBgn0020653 \\
Relish & TTAGGTGCGGTCTGCTT & CTCTCCAGTTGTGCCGACT & FBgn0014018 \\
GPDH & ATGGAGATGATTCGCTTCGT & GCTCCTCAATGGTTTTCCA & FBgn0001128 \\
B-Tubulin & ATCCCCAACAACGTGAAGAC & ACCAATGCAAGAAAGCCTG & FBgn0284243 \\
\hline
\end{tabular}


Reactions were carried out in $20 \mu \mathrm{L}$ final volume with 2.5 $\mathrm{ng} / \mu \mathrm{L}$ of cDNA, 1x PCR buffer, $0.2 \mu \mathrm{M}$ of each primer (Table 1), $0.2 \mathrm{mM}$ dNTP, $1.5-5 \mathrm{mM} \mathrm{MgCl}_{2}, 0,1 \mathrm{x} \mathrm{SYBR}^{\circ}$ Green, and $0.02 \mathrm{U}$ platinum Taq DNA polymerase (Invitrogen ) using 40 therm cycles of $15 \mathrm{~s}$ at $94{ }^{\circ} \mathrm{C}, 15 \mathrm{~s}$ at $60^{\circ} \mathrm{C}$, and $15 \mathrm{~s}$ at $72^{\circ} \mathrm{C}$ [72]. SYBR fluorescence was analyzed by Software StepOne 2.0 version (Applied Biosystems). The reactions were performed in duplicates of four to six independent experiments. Dissociation curves at 55 to $99^{\circ} \mathrm{C}$ were obtained to confirm the amplification of a single specific product per reaction. The $2^{-\Delta \Delta C T}$ method [73] was used to establish the values of the genic expression.

\section{Statistical analyses}

All results were expressed as mean \pm SEM. Data on survival percentage were plotted in the Kaplan-Meier curve and analyzed by Logrank test for trend. Data derived from the biochemical analyses (DCFDA oxidation, GST and AChE activity) were analyzed by Four-way ANOVA [2 with/without $\mathrm{VCH} \times 2$ with/without $\mathrm{MeHg}^{+} \times 2$ flies ages (four and six-days-old) $x$ time of kinetic reading (reading (or reaction) time was treated as repeated measures)]. The main effect and lower-order interactions will be discussed only when higher-order interactions were statistically not significant. Data from mRNA levels were analyzed by paired $t$-test. The results were considered significant when $p \leq 0.05$.

\section{Results}

\section{Concentration curve for $\mathrm{MeHg}^{+}$}

As shown in the Kaplan-Meier survival curve (Fig. 1a), a Logrank test for trend indicated a significant difference among the groups [Chi square $(1)=9.72, p=0.0018$ ]. Exposure of flies to $0.4 \mathrm{mM} \mathrm{MeHg}$ for four days caused a significant reduction in survival when compared to the control group. In contrast, exposure to 0.1 or $0.2 \mathrm{mM}$ $\mathrm{MeHg}^{+}$did not alter the survival rate.

\section{Percent survival of flies after co-exposure to $\mathrm{VCH}$ and $\mathrm{MeHg}^{+}$}

Flies from both genders were exposed to $0.1 \%$ ethanol (control group), $1 \mathrm{mM} \mathrm{VCH}, 0.2 \mathrm{mM} \mathrm{MeHg}^{+}$, and $1 \mathrm{mM}$ $\mathrm{VCH}+0.2 \mathrm{mM} \mathrm{MeHg}{ }^{+}$for one or three days. Logrank test for trend indicated no alterations in flies exposed and co-exposed to $\mathrm{VCH}$ and $\mathrm{MeHg}^{+}$for one day [Chi square $(1)=1.647, p=0.19]$ (Fig. 1b). In contrast, threedays co-exposure to $\mathrm{VCH}$ and $\mathrm{MeHg}^{+}$led to a significant decrease in percent survival ([Chi square $(1)=$ 16.61, $p<0.0001]$; Fig. 1c).

\section{Negative geotaxis}

The flies locomotion was not affected by exposure and co-exposure to $\mathrm{VCH}$ and $\mathrm{MeHg}^{+}$for one or three days as verified by percent of climbing (Fig. $2 a$ and b, respectively).

\section{Dichlorofluorescein diacetate oxidation}

For DCFDA oxidation, the between-subjects part of the four-way ANOVA revealed a significant interaction between $\mathrm{MeHg}^{+} \mathrm{x}$ age in the flies' head. The interaction was significant, because, after one day of exposure, $\mathrm{MeHg}^{+}$significantly decreased the oxidation of DCFDA in the head, whereas DFCDA oxidation increased after three days of exposure $[\mathrm{F}(1$, 88 ) $=4.96, p<0.03$ (Fig. 3 a-d and Table 2)]. The within-subjects part of the ANOVA indicated a significant $\mathrm{MeHg}^{+} \mathrm{x}$ age $\mathrm{x}$ time of kinetic reading. The analysis of DCFDA oxidation as a function of reaction time (Fig. 3a and c) confirmed that the increase
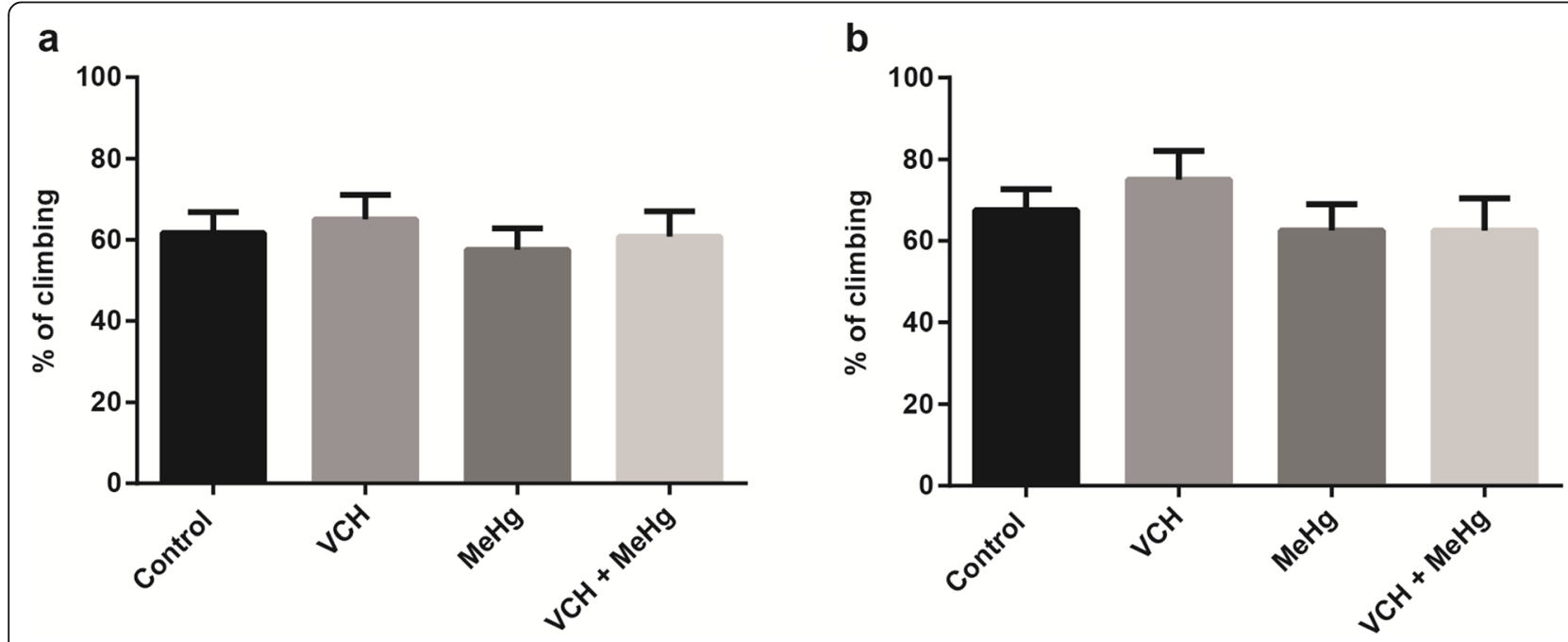

Fig. 2 Percent of climbing of flies after exposure and co-exposure to $\mathrm{VCH}$ and $\mathrm{MeHg}^{+}$for one (a) or three days (b). Data were expressed as the mean \pm standard error. Results were analyzed by Two-way ANOVA (VCH x MeHg ${ }^{+}$as independent factors) ( $\left.p>0.05\right)$ 


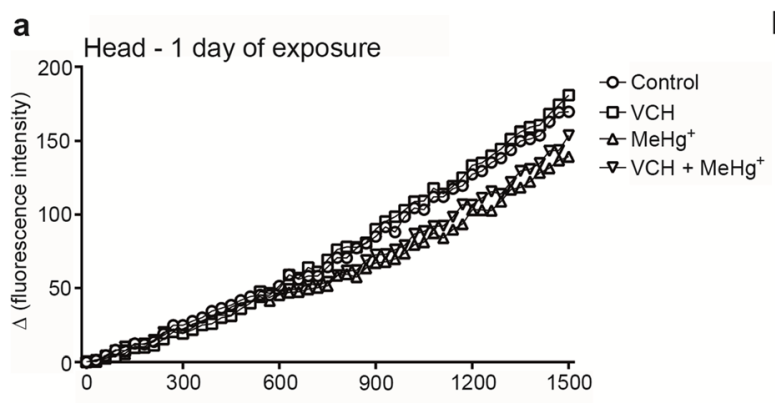

b

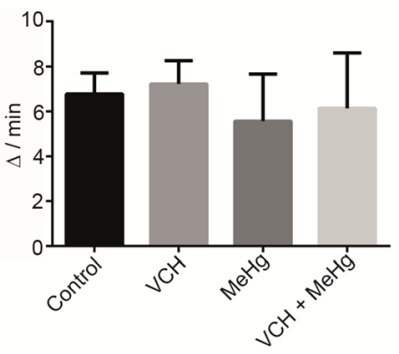

C

d
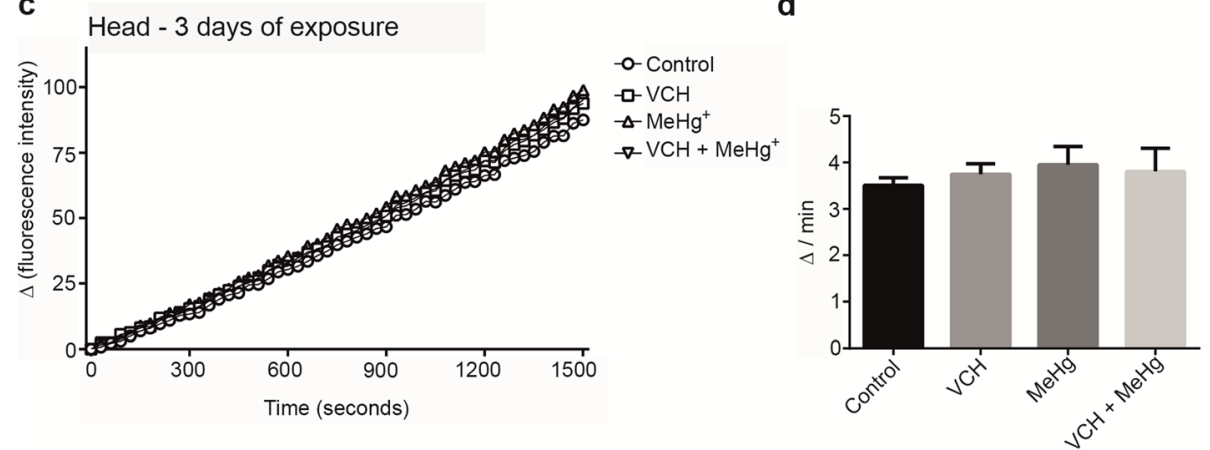

Fig. 3 DCFDA oxidation of flies head after exposure and co-exposure to $\mathrm{VCH}$ and $\mathrm{MeHg}^{+}$for one (a and $\mathbf{b}$ ) or three days (c and $\mathbf{d}$ ). Kinetic readings were expressed as the mean in $\mathbf{a}$ and $\mathbf{c}$ (standard errors were omitted for better viewing) and delta per minute as mean \pm standard error in $\mathbf{b}$ and $\mathbf{d})$. Results were analyzed by four-way ANOVA ( $\mathrm{CH} \times \mathrm{MeHg}^{+} \times$age $x$ time of kinetic reading which was treated as repeated measures) and were considered significantly different when $p<0.05$

in oxidation of DCFDA decreased after one day of exposure to $\mathrm{MeHg}^{+}$, but increased after three days of exposure relative to the control group $[\mathrm{F}(49,4312)=$ 5.41, $p<0.001$ (Table 2)]. The main and interactive effects associated with $\mathrm{VCH}$ exposure were not significant (data were not shown).

Multifactorial ANOVA revealed a significant thirdorder interaction ( $\mathrm{VCH} \times \mathrm{MeHg}^{+} \mathrm{x}$ age) in the body. This interaction was significant, because after one day of exposure to $\mathrm{VCH}, \mathrm{MeHg}^{+}$or $\mathrm{VCH}+\mathrm{MeHg}^{+}$ the oxidation of DCFDA was increased, whereas after three days of exposure only simultaneous exposure to $\mathrm{VCH}$ and $\mathrm{MeHg}^{+}$increased the oxidation of DCFDA $[\mathrm{F}(1,88)=4.97 ; p<0.03$ (Fig. 4a-d and Table 2)]. The within-subjects part of the ANOVA indicated a significant fourth-order interaction (reaction time $\mathrm{x} \mathrm{VCH} \times \mathrm{MeHg}^{+} \mathrm{x}$ age). The analysis of DCFDA oxidation as a function of reaction time (Fig. 4a and c) demonstrated that the increase in oxidation of DCFDA was inherent to all treatments after one day of exposure, but it was increased only upon the simultaneous exposure to $\mathrm{VCH}$ and $\mathrm{MeHg}^{+}$ after three days of exposure $[\mathrm{F}(49,4312)=3.74 ; p<$ 0.001 (Table 2)].

\section{Glutathione S-transferase activity}

For GST activity in the flies' head, the betweensubjects part of the four-way ANOVA revealed a significant main effect of age, given that the younger flies (one day of exposure) exhibited higher head GST activity than older flies (three days of exposure) $[\mathrm{F}(1,88)=94.78 ; p<0.001$ (Fig. 5a-d and Table 3) .

Table 2 Statistical analyses of DCFDA oxidation

\begin{tabular}{|c|c|c|c|c|c|}
\hline Tissue & ANOVA & Interaction & DF & $\mathrm{F}$ & $P$ \\
\hline \multirow[t]{2}{*}{ Head } & Between-subjects & $\mathrm{MeHg}^{+} \times \mathrm{age}^{\mathrm{a}}$ & 1,88 & 4.96 & 0.03 \\
\hline & Within-subjects & $\mathrm{MeHg}^{+} x$ age $x$ time $^{b}$ & 49,4312 & 5.41 & $<0.001$ \\
\hline \multirow[t]{2}{*}{ Body } & Between-subjects & $\mathrm{VCH} \times \mathrm{MeHg}^{+} \times$age & 1,88 & 4.97 & 0.03 \\
\hline & Within-subjects & Time $\times \mathrm{VCH} \times \mathrm{MeHg}^{+} \times$age & 49,4312 & 3.74 & $<0.001$ \\
\hline
\end{tabular}

${ }^{\mathrm{a} A t}$ the end of exposure periods (one or three days) flies had ages of four and six-days-old, respectively. ${ }^{\mathrm{b}}$ Reaction time 


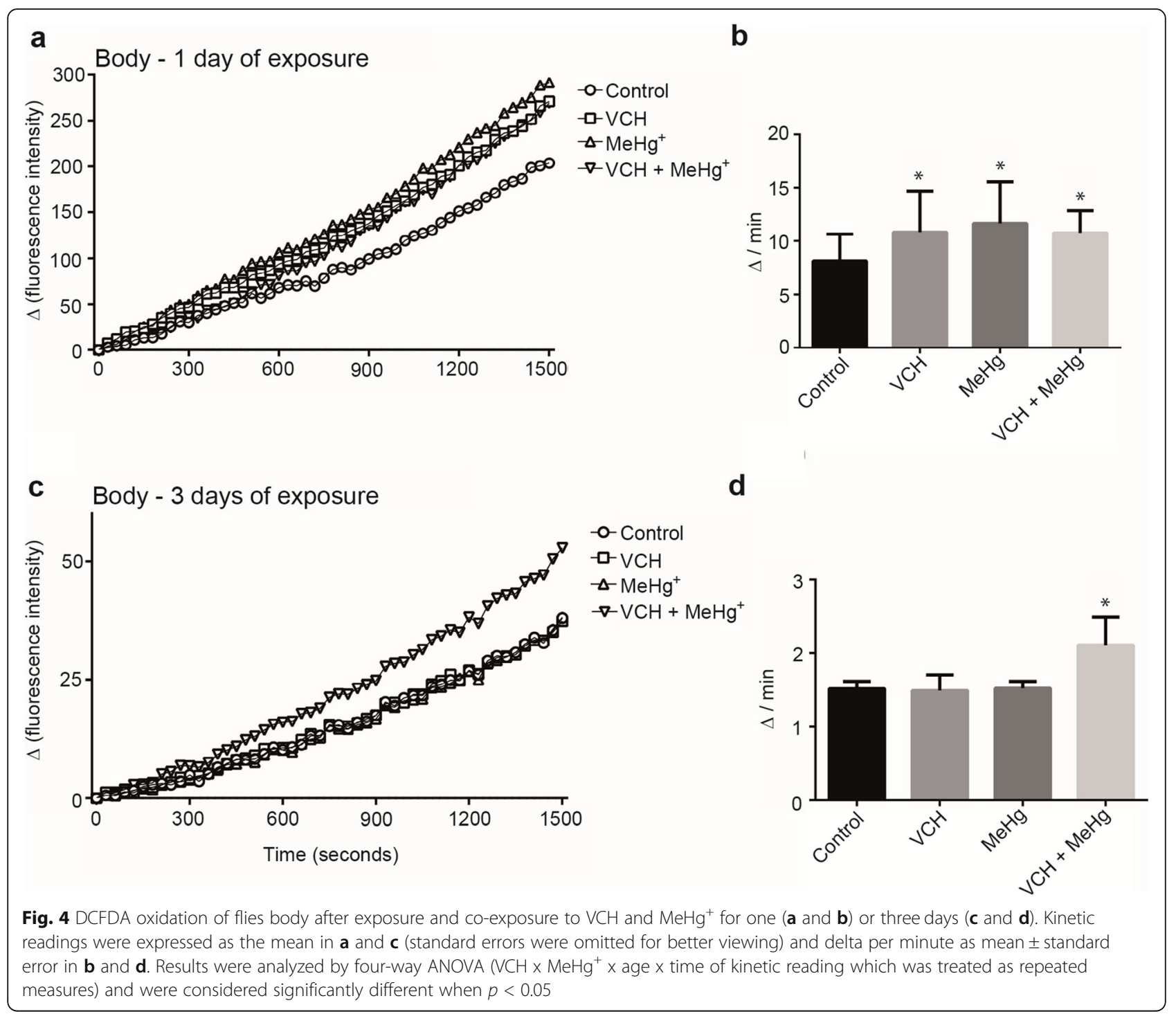

The within-subjects part of the ANOVA indicated a significant reaction time $\mathrm{x} V \mathrm{VCH}$ interaction. The analysis of head GST activity as a function of reaction time (Figs. 5a and c) confirmed that the $\mathrm{VCH}$ increased GST activity after one day of exposure, but had no effect after three days of exposure $[\mathrm{F}(47$, $4136)=5.55 ; p<0.001 \quad($ Table 3$)]$. There was also a third-order interaction (reaction time $\mathrm{x} \mathrm{MeHg}^{+} \mathrm{x}$ age).

In the body, the between-subjects part of the fourway ANOVA revealed a significant main effect of age, because the GST activity of younger flies (one day of exposure) was higher than in older flies (three days of exposure) $[\mathrm{F}(1,88)=300.19 ; \quad p<0.001$ (Fig. 6a-d and Table 3)]. There was also an interaction between $\mathrm{VCH} \times \mathrm{MeHg}^{+}$in the body of the flies. The interaction was significant, because after one day of treatment with $\mathrm{VCH}, \mathrm{MeHg}^{+}$, and $\mathrm{VCH}+$ $\mathrm{MeHg}^{+}$GST increased, whereas only $\mathrm{MeHg}^{+}$increased it after three days of exposure $[\mathrm{F}(1,88)=$ 4.62; $p>0.04$ (Table 3)]. The within-subjects part of the ANOVA showed a significant fourth-order interaction (reaction time $\mathrm{x} \mathrm{VCH} \times \mathrm{MeHg}^{+} \mathrm{x}$ age). The analyses of GST activity as a function of reaction time (Fig. 6a and c) demonstrated increased GST activity in all treatments after one day of exposure, but it was increased only upon three days of exposure to $\mathrm{MeHg}^{+}[\mathrm{F}(47,4136)=1.96 ; \mathrm{p}<0.001$ (Table 3) $]$.

\section{Acetylcholinesterase activity}

The between-subjects part of the four-way ANOVA on AChE activity in the head of flies revealed a significant main effect of age, as the AChE activity of younger flies (one day of exposure) was lower than 


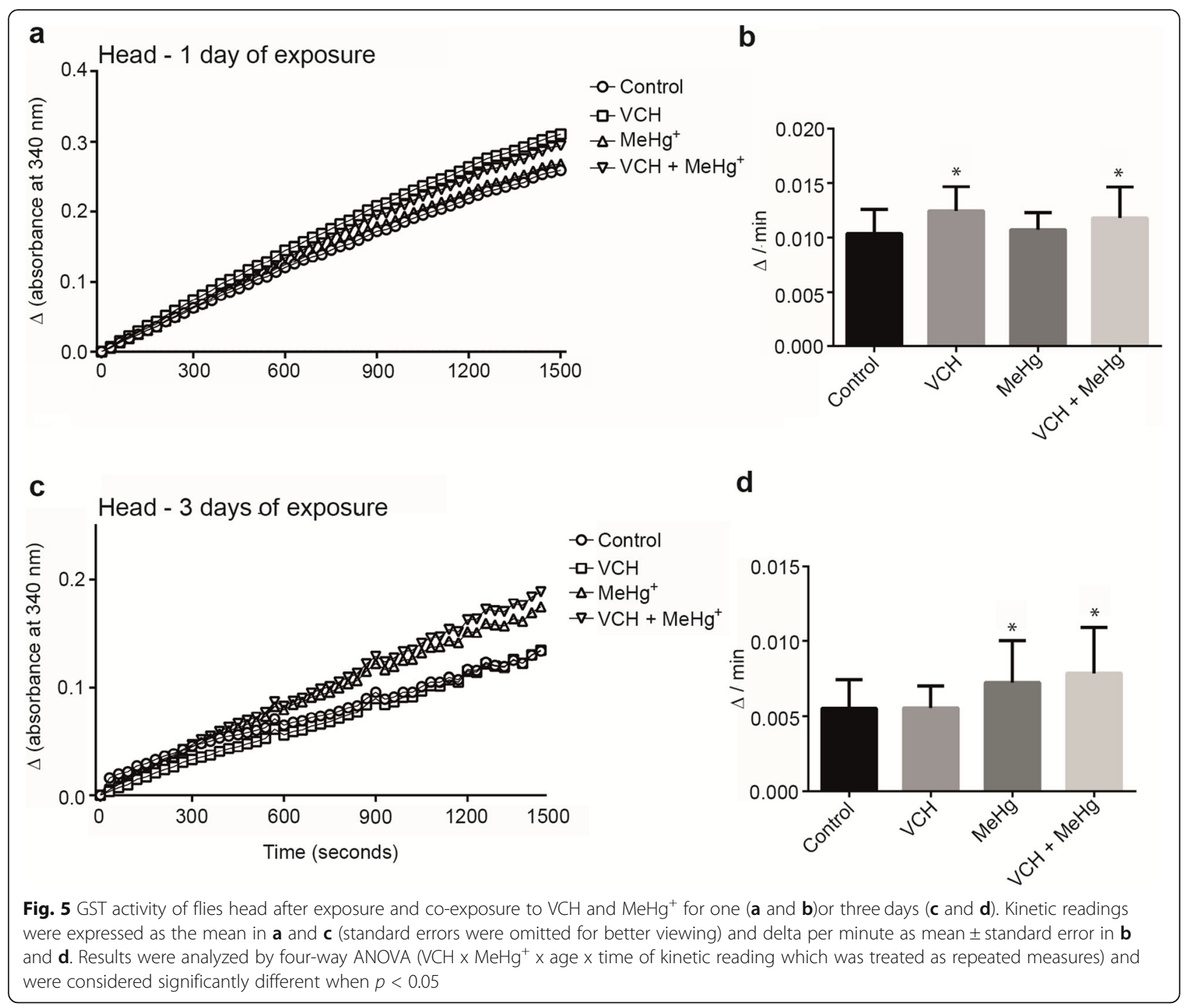

in older flies (three days of exposure) $[\mathrm{F}(1,88)=$ 216.02; p $<0.001$ (Fig. 7a-d and Table 4)]. The analysis of AChE activity as a function of reaction time (Fig. $7 \mathrm{a}$ and $\mathrm{c}$ ) indicated a third-order interaction (reaction time $\mathrm{x} \mathrm{VCH} \times \mathrm{MeHg}^{+}$), since $\mathrm{VCH}$ increased the AChE activity after one day of exposure, but returned to basal levels after three days of exposure. In contrast, $\mathrm{MeHg}^{+}$caused an increase in AChE activity after three days of exposure, but not after one day of exposure (where $\mathrm{VCH}$ tended to increase the enzyme activity) $[\mathrm{F}(4,352)=2.6 ; p<0.04$ (Table 4)].

Table 3 Statistical analyses of GST activity

\begin{tabular}{|c|c|c|c|c|c|}
\hline Tissue & ANOVA & Interaction & DF & $\mathrm{F}$ & $p$ \\
\hline \multirow[t]{3}{*}{ Head } & Between-subjects & $\mathrm{Age}^{a}$ & 1,88 & 94.78 & $<0.001$ \\
\hline & Within-subjects & Time $^{b} \times$ VCH & 47,4136 & 5.55 & $<0.001$ \\
\hline & & Time $x \mathrm{MeHg}^{+} x$ age & 47,4136 & 6.62 & $<0.001$ \\
\hline \multirow[t]{3}{*}{ Body } & Between-subjects & Age & 1,88 & 300.19 & $<0.001$ \\
\hline & & $\mathrm{VCH} \times \mathrm{MeHg}^{+}$ & 1,88 & 4.62 & 0.03 \\
\hline & Within-subjects & Time $\times \mathrm{VCH} \times \mathrm{MeHg}^{+} \times$age & 47,4136 & 1.96 & $<0,001$ \\
\hline
\end{tabular}

${ }^{\mathrm{a}}$ At the end of exposure periods (one or three days) flies had ages of four and six-days-old, respectively. ${ }^{\mathrm{b}}$ Reaction time 


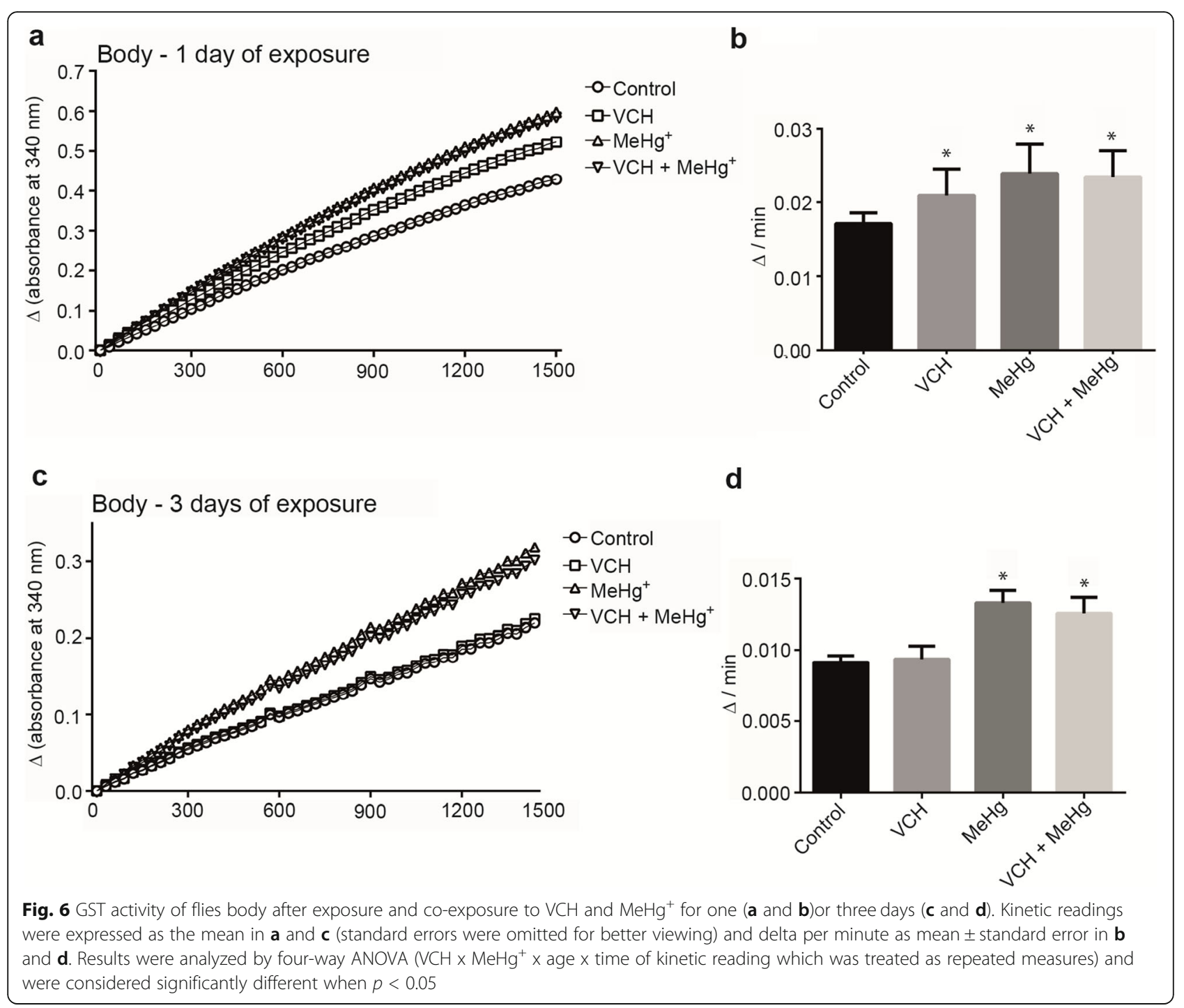

\section{Gene expression}

Expression of genes involved in oxidative stress and inflammatory responses of flies upon exposure and coexpure to $\mathrm{VCH}$ and $\mathrm{MeHg}^{+}$for three days are shown in Figs. 8, 9 and 10. Figure 8 depicts the expression of Nrf2 and Keap1 in the head (Fig. 8a and c) and the body (Fig. $8 \mathrm{~b}$ and d). Treatment with $\mathrm{VCH}, \mathrm{MeHg}^{+}$or $\mathrm{VCH}+\mathrm{MeHg}^{+}$did not alter mRNA levels of Nrf2 and Keap1 in both head and body.

mRNA levels of genes related to oxidative stress (Jafrac1 and TrxR1) is shown in Fig. 9. Exposure to $\mathrm{VCH}, \mathrm{MeHg}^{+}$or $\mathrm{VCH}+\mathrm{MeHg}^{+}$did not alter Jafrac1 (Fig. 9a and b) and TrxR1 (Fig. 9c and d) expression levels in both tissues.

Expression of the NF- $\mathrm{kB}$ activating protein-like (Fig. 10a and b) and Relish (Fig. 10c and d) genes were evaluated. $\mathrm{MeHg}^{+}$caused a significant upregulation of Relish in body of flies $(p=0.03)$. The treatments unaltered the mRNA levels of NF- $\mathrm{kB}$ activating protein-like (head and body) and Relish (head).

\section{Discussion}

To maintain redox homeostasis in aerobic organisms, a complex interplay between various classes of proteins, such as transcription factors, antioxidant enzymes and electron donating molecules must occur [74]. Reactive oxygen or nitrogen species are continuously formed as byproducts of physiologic reactions [75]. However, xenobiotics can trigger an imbalance in redox homeostasis, causing either direct damage to biomolecules or directly promoting oxidative stress. Exposure to electrophilic xenobiotics can disrupt the cellular redox balance and change the expression of various classes of genes [76, 77]. 


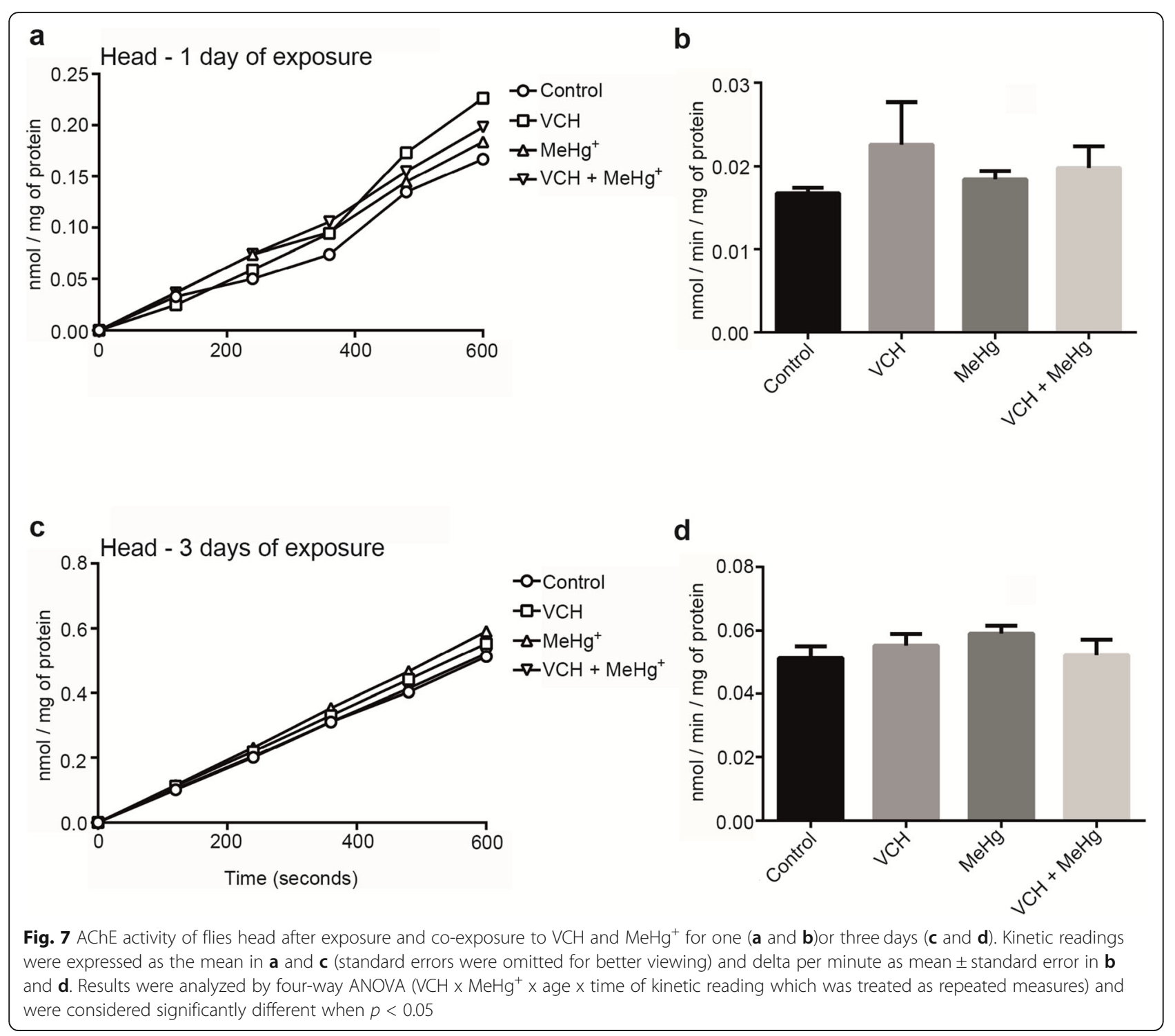

Here we observed that $\mathrm{VCH}, \mathrm{MeHg}^{+}$, or $\mathrm{VCH}+$ $\mathrm{MeHg}^{+}$caused oxidative stress in the body of flies after one day of exposure. Also, co-exposure to $\mathrm{VCH}$ and $\mathrm{MeHg}^{+}$for three days caused oxidative stress in the flies' body. These results corroborate earlier studies where individual exposures to $\mathrm{MeHg}^{+}$or $\mathrm{VCH}$ were shown to increase reactive species production in various animal models [16, 43, 44, 78-80].

Since reactive metabolites of $\mathrm{VCH}$ and $\mathrm{MeHg}^{+}$can form adducts with proteins containing soft nucleophile centers, we determined the activity of GSTs. The latter are considered biomarkers of toxicity to environmental contaminants [81-83]. GSTs are a family of enzymes that catalyze phase II detoxification reactions and conjugate reduced GSH with electrophilic molecules [84-88]. In the head of flies, $\mathrm{VCH}$ led to increased GST activity after one day of exposure, while $\mathrm{MeHg}^{+}$and $\mathrm{VCH}+$ $\mathrm{MeHg}^{+}$increased GST activity only after three days of exposure. In the body, $\mathrm{VCH}, \mathrm{MeHg}^{+}$, and $\mathrm{VCH}+\mathrm{MeHg}^{+}$ increased the enzyme's activity after one day of

Table 4 Statistical analyses of AChE activity

\begin{tabular}{llllll}
\hline Tissue & ANOVA & Interaction & DF & F & P \\
\hline Head & Between-subjects & Age $^{\mathrm{a}}$ & 1,88 & 216,02 & $<0.001$ \\
& Within-subjects & Time $^{\mathrm{b}} \times \mathrm{VCH} \times \mathrm{MeHg}^{+}$ & 4352 & 2,60 & 0.04 \\
\hline
\end{tabular}

${ }^{\mathrm{a}}$ At the end of exposure periods (one or three days) flies had ages of four and six-days-old, respectively. ${ }^{\mathrm{b}}$ Reaction time 


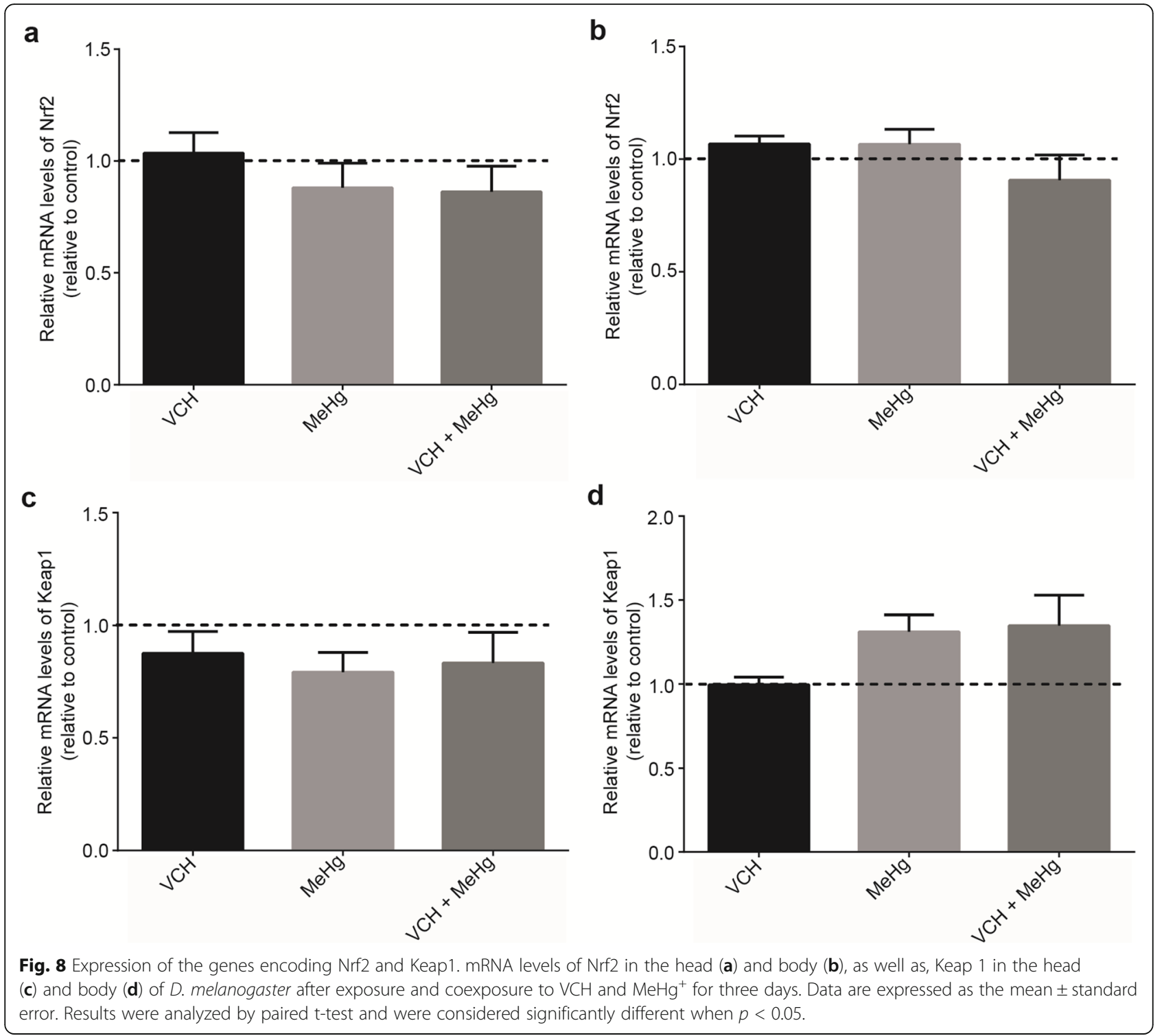

exposure, and $\mathrm{MeHg}^{+}$and $\mathrm{VCH}+\mathrm{MeHg}^{+}$increased it after three days of exposure. GSTs catalyze the conjugation of $\mathrm{VCH}$ metabolites [39-41] with GSH, preventing their interaction with target proteins. The increase in GST activity may be related to an adaptive response that counteracts the electrophile toxicity inherent to $\mathrm{VCH}$. An analogous process of detoxification might occur with GSH and $\mathrm{MeHg}^{+}[33,38]$. However, there are contradictory studies, where exposure to $\mathrm{MeHg}^{+}$induces either an increase or decrease in GST activity, dependent upon the experimental model and the tissues analyzed [8991]. Here, we observed an intricate pattern of changes in total GST activity, which was dependent upon the tissue, the type of chemical, and the period of exposure. Notably, the enzyme activity increased after exposure to $\mathrm{VCH}, \mathrm{MeHg}^{+}$, and $\mathrm{VCH}+\mathrm{MeHg}^{+}$. This likely reflects a compensatory response to counteract the toxicity of both xenobiotics, consistent with recent observations in D. melanogaster, where several GST isoforms (GSTD1, GSTE1, and GSTS1) have been shown to protect larvae during pupal development and knockdown of GSTE1, and GSTS1 isoforms increased the susceptibility to $\mathrm{MeHg}^{+}$toxicity [38].

Previously, we and other researches have shown that AChE can be used as a biomarker of exposure to xenobiotics [92-95]. Early studies have demonstrated the inhibition of AChE after exposure to $\mathrm{MeHg}^{+}$in flies, cockroaches, and rats [96-98], as well as after exposure to $\mathrm{VCH}$ in flies [43], yet, here we failed to observe inhibition of the enzyme. Inhibition of AChE activity can be associated with impairments in fly locomotion [43, 44]. The flies' behavior 

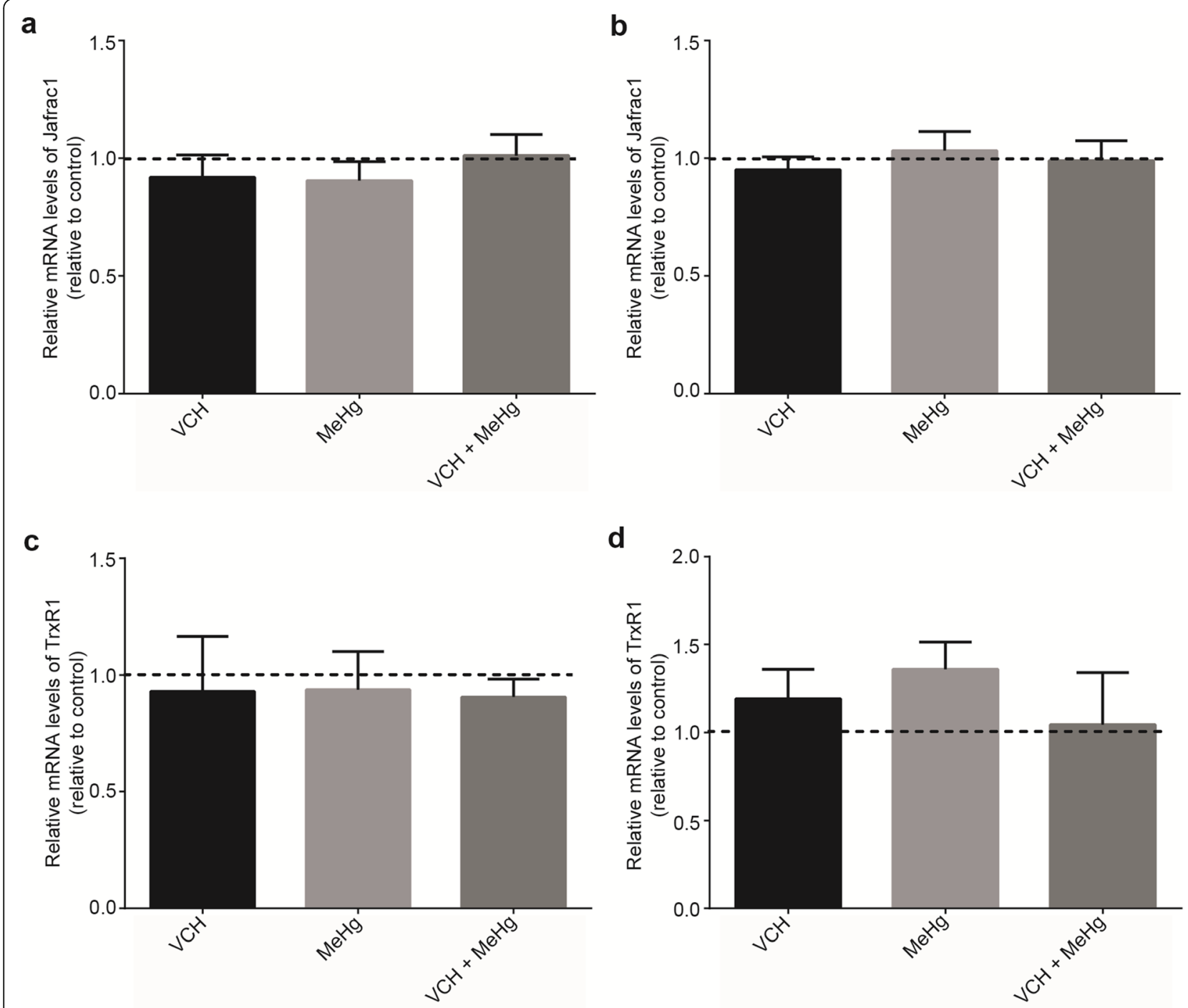

Fig. 9 Expression of the genes encoding Jafrac1 and TrxR1. mRNA levels of Jafrac1 in the head (a) and body (b), TrxR1 in the head (c) and body (d) of D. melanogaster after exposure and co-exposure to $\mathrm{VCH}$ and $\mathrm{MeHg}^{+}$for three days. Data are expressed as the mean \pm standard error. Results were analyzed by paired t-test and were considered significantly different when $p<0.05$

was unaltered, which is consistent with unaltered AChE activity. Probably the exposure period and/or doses of the toxicants were not sufficient to alter this enzyme and, consequently, to reflect on the behavior of the flies.

Among proteins that are related to oxidative stress, KEAP1 represses the translocation of the NRF2 to the nucleus $[99,100]$. Once in the nucleus, NRF2 binds to the antioxidant response element (ARE or electrophile response element or EpRE), an enhancer ciselement, stimulating the expression of stressresponsive genes [101]. In D. melanogaster, this mechanism is analogous to the one reported in mammals. NRF2 in flies is referred to as $\mathrm{CncC}$, and it is part of the transcription factor family Cap'n'collar
[102, 103], which activates many cytochrome P450 and GST coding genes [103-105]. The gene CG3962 encodes a Kelch protein, which is similar to KEAP1 [103]. Nrf2 and Keap1 expression in the flies were not altered upon three-days exposure to $\mathrm{VCH}$ and $\mathrm{MeHg}^{+}$. Since $\mathrm{MeHg}^{+}$or VCH increased GST activity, we expected to find an increase in the expression of Nrf2 and Keap1. Indeed, literature data have indicated an essential role for this transcription factor in the toxicity of $\mathrm{MeHg}^{+}$[106-108]. However, their expression did not differ from control flies. It is plausible that the expression of several isoforms of GST that are not under the control of NRF2 or that the activation of this transcription factor has occurred in a KEAP1-independent form. Next, we tested genes 

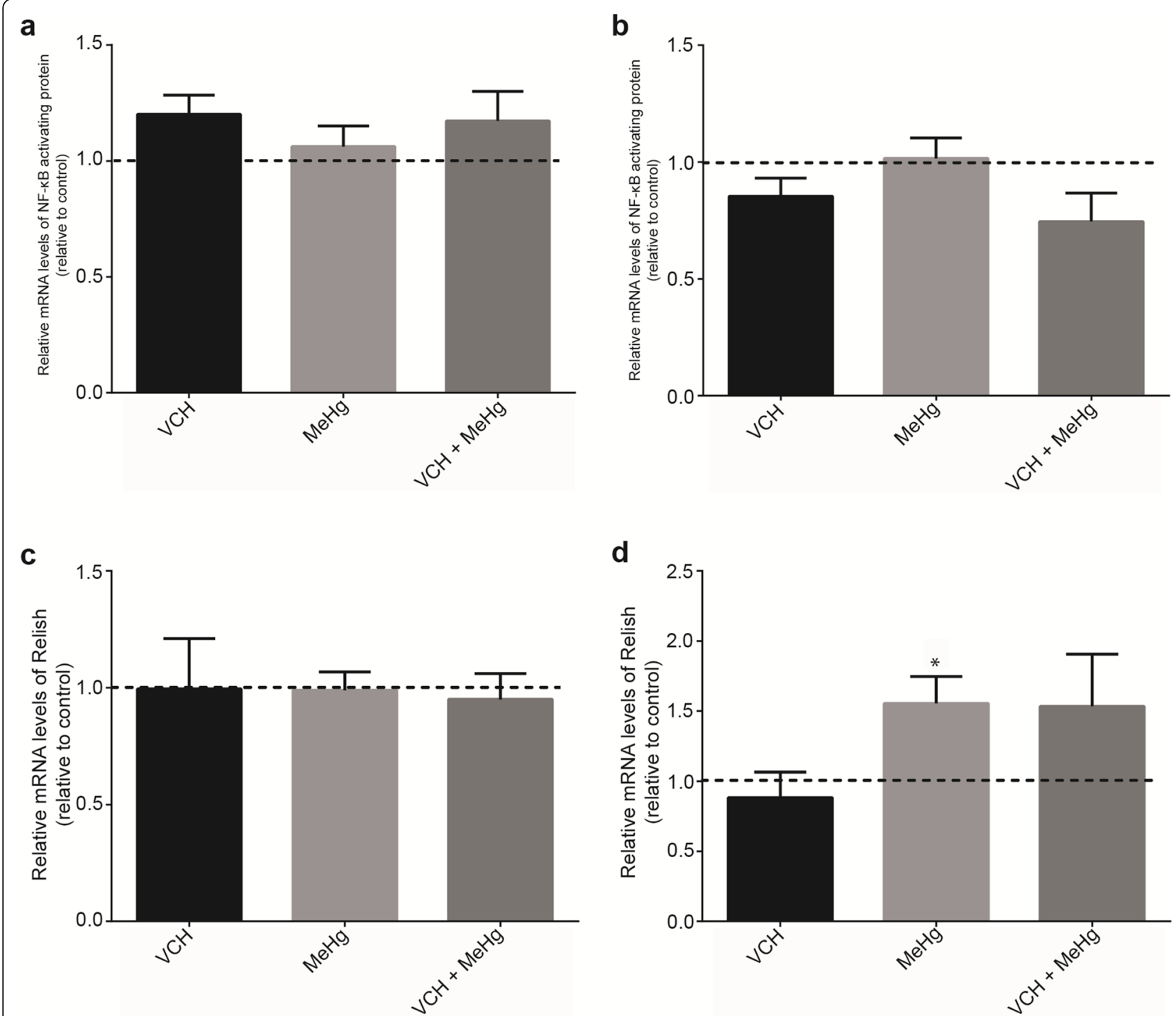

Fig. 10 Expression of the genes encoding NF-KB activating protein and Relish. mRNA levels of NF-KB activating protein in the head (a) and body (b), Relish in the head (c) and body (d) of D. melanogaster after exposure and co-exposure to VCHand $\mathrm{MeHg}^{+}$for three days. Data are expressed as the mean \pm standard error. Results were analyzed by paired t-test and were considered significantly different when $p<0.05$

directly related to oxidative stress metabolism. Peroxiredoxins are a family of enzymes that reduce $\mathrm{H}_{2} \mathrm{O}_{2}$ or organic peroxides to $\mathrm{H}_{2} \mathrm{O}$ or $\mathrm{R}-\mathrm{OH}$, respectively [54]. D. melanogaster expresses seven peroxiredoxins, including Jafrac1 that is homolog to Prx2 of mammals [109]. Herein, the Jafrac1 expression was not altered by three-days exposure to $\mathrm{VCH}$ and $\mathrm{MeHg}^{+}$. Thioredoxins (Trx) are a family of small proteins with redox active thiol groups, which can donate reducing equivalents to various proteins. The oxidation of reduced $\operatorname{Trx}\left[\operatorname{Trx}(-\mathrm{SH})_{2}\right]$ forms the oxidized $\operatorname{Trx}\left[\operatorname{Trx}(\mathrm{S})_{2}\right]$ that may undergo further reduction by NADPH-dependent TrxR, thus restoring $\operatorname{Trx}\left[\operatorname{Trx}(-\mathrm{SH})_{2}\right]$ [110]. Here, the mRNA levels of TrxR1 were not altered by $\mathrm{VCH}$ and $\mathrm{MeHg}^{+}$. Finally, to understand whether simultaneous exposure to $\mathrm{VCH}$ and $\mathrm{MeHg}^{+}$might activate select inflammatory responses, we analyzed the mRNA levels of NF- $\mathrm{kB}$ activating protein and Relish. NF- $\mathrm{kB}$ belongs to a ubiquitous dimer family that regulates the expression of a large number of genes involved in immune regulation, inflammatory responses, and antiapoptotic effects [111]. In the present study, after three-days exposure, $\mathrm{MeHg}^{+}$induced upregulation of the Relish in the body of the flies. In D. melanogaster three NF- $\kappa B /$ Rel proteins have been identified, e.g., Relish, Dif, and Dorsal [112, 113]. Exogenous environmental factors selectively activate the NF- $\kappa B /$ Rel proteins of $D$. melanogaster. Here we observed the upregulation of Relish in the body of flies exposed to $\mathrm{MeHg}^{+}$for three days. Since Relish is involved in 
inflammatory processes in flies, we speculate that $\mathrm{MeHg}^{+}$may activate inflammatory responses via this route.

One limitation of our study is the absence of data about the $\mathrm{VCH}$ and $\mathrm{MeHg}^{+}$absorption in flies. Concerning the distribution of $\mathrm{MeHg}^{+}$, large amounts of $\mathrm{MeHg}^{+}$ were found in adult fly's brain after oral exposure [114]. As for $\mathrm{VCH}$, there are no data in the literature on the rate of absorption and distribution in living organisms. Consequently, future studies have to be done to clarify these topics about the distribution of $\mathrm{VCH}$ and $\mathrm{MeHg}^{+}$ in flies.

\section{Conclusions}

The results presented herein indicate that $\mathrm{VCH}$ and $\mathrm{MeHg}^{+}$, when co-administered, did not potentiate their individual effects in flies. In general, $\mathrm{MeHg}^{+}$ modified a higher number of endpoints than did $\mathrm{VCH}$, likely reflecting its higher electrophilicity. Our findings established that Relish might be an early molecular marker of $\mathrm{MeHg}^{+}$toxicity. Furthermore, the response of GSTs to both toxicants indicates that the study of the expression of specific isoforms of this gene family might contribute to better understanding the molecular mechanisms involved in the toxicity of two important environmental contaminants. Additional genes associated with oxidative stress and inflammatory response should be studied as possible toxicity markers. The development and standardization of biomarkers of exposure for the detection of early toxicological changes induced by low concentration of toxic agents are criticalin predicting and preventing chronic exposure effects.

\section{Abbreviations \\ AChE: Acetylcholinesterase; DCFDA: 2,7-dichlorofluorescein diacetate; GSH: Glutathione; GST: Glutathione S-transferase; Keap1: Kelch-like erythroid cell-derived associated protein 1; $\mathrm{MeHg}^{+}$: Methylmercury; Nrf2: Nuclear factor-erythroid 2-related factor 2; TrxR: Thioredoxin reductase; VCD: 4- vinylcyclohexene diepoxide; VCH: 4-vinylcyclohexene}

\section{Acknowledgments}

The authors would like to appreciate the Universidade Federal de Santa Maria provided facilities for the bioassays.

\section{About this supplement}

This article has been published as part of BMC Pharmacology and Toxicology Volume 20 Supplement 1, 2019: Proceedings of Toxi-Latin 2018. The full contents of the supplement are available online at https://bmcpharmacoltoxicol.biomedcentral.com/articles/supplements/ volume-20-supplement-1.

\section{Authors' contributions}

BCP performed the biochemical assays, the statistical analyses and wrote the manuscript. CSO contributed to experimental design and with FDS performed the flies exposure systems and sample preparation. ALAS and BCP realized the molecular biology assays. JBTR and MA contributed to experimental design, supervised the assays, oriented the statistical analyses, and corrected the manuscript. All authors contributed to writing and approved the final manuscript.

\section{Funding}

Publication costs are funded by Coordenação de Aperfeiçoamento de Pessoal de Nível Superior (CAPES/PROEX: n 88882.182155/2018-

01; 23038.004173/2019-93; nº493/2019), FAPERGS/CNPq, 12/2014-PRONEX:

no 16/2551-0000, INCT-EN: For Cerebral Diseases, Excitotoxicity and

Neuroprotection, and FAPERGS/CAPES 04/2018 DOCFIX:

33581.466.15808.03042018.

\section{Availability of data and materials}

The datasets analyzed during the current study are available from the corresponding author on reasonable request.

Ethics approval and consent to participate

Not applicable

Consent for publication

Not applicable

\section{Competing interests}

The authors declare that they have no competing interests.

\section{Author details}

1Departamento de Bioquímica e Biologia Molecular, Centro de Ciências Naturais e Exatas, Universidade Federal de Santa Maria, Santa Maria, RS, Brazil. ${ }^{2}$ Programa Pós-Graduação Stricto Sensu em Biotecnologia Aplicada a Saúde da Criança e do Adolescente, Instituto de Pesquisa Pelé Pequeno Príncipe, Curitiba, Paraná, Brazil. 'Faculdades Pequeno Príncipe, Curitiba, Paraná, Brazil. ${ }^{4}$ Department of Molecular Pharmacology, Albert Einstein College of Medicine, Bronx, NY, USA.

Published: 19 December 2019

\section{References}

1. Grandjean P, Landrigan PJ. Developmental neurotoxicity of industrial chemicals. The Lancet. 2006;368:2167-78.

2. Karri V, Schuhmacher $\mathrm{M}$, Kumar $\mathrm{V}$. Heavy metals $(\mathrm{Pb}, \mathrm{Cd}$, As and $\mathrm{MeHg}$ ) as risk factors for cognitive dysfunction: A general review of metal mixture mechanism in brain. Environ Toxicol Pharmacol. 2016;48:203-13.

3. Tousova Z, Oswald P, Slobodnik J, Blaha L, Muz M, Hu M, Brack W, Krauss M, Di Paolo C, Tarcai Z, Seiler TB, Hollert H, Koprivica S, Ahel M, Schollée JE, Hollender J, Suter MJF, Hidasi AO, Schirmer K, Sonavane M, Ait-Aissa S, Creusot N, Brion F, Froment J, Almeida AC, Thomas K. European demonstration program on the effect-based and chemical identification and monitoring of organic pollutants in European surface waters. Sci Total Environ. 2017:601-602:1849-68.

4. Huff J. Carcinogenicity bioassays of bisphenol A, 4-vinylcyclohexene diepoxide, and 4-vinycyclohexene. Toxicol Sci. 2001;64:282-3.

5. Gonçalves LVF, Azevedo EB, Aquino-Neto FR, Billa DM, Sant'Anna GL Jr, Dezotti M. Treatment of an industrial stream containing vinylcyclohexene by the $\mathrm{H}_{2} \mathrm{O}_{2}$ /UV process. Environ Sci Pollut Res. 2016;23:19626-33.

6. NTP (National Toxicology Program). Toxicology and carcinogenesis studies of 4-vinyl-1-cyclohexene diepoxide (CAS No. 106-87-6) in F344/N rats and B6C3F1 mice (dermal studies). Natl Toxicol Program Tech Rep Ser. 1989;362: $1-249$.

7. Bevan C, Stadler JC, Elliott GS, Frame SR, Baldwin JK, Leung HW, Moran E, Panepinto AS. Subchronic toxicity of 4-vinylcyclohexene in rats and mice by inhalation exposure. Fundam Appl Toxicol. 1996;32:1-10.

8. Cannady EA, Dyer CA, Christian PJ, Sipes IG, Hoyer PB. Expression and activity of microsomal epoxide hydrolase in follicles isolated from mouse ovaries. Toxicol Sci. 2002;68:24-31.

9. Keating AF, Rajapaksa KS, Sipes G, Hoyer PB. Effect of CYP2E1 gene deletion in mice on expression of microsomal epoxide hydrolase in response to VCD exposure. Toxicol Sci. 2008;105:351-9.

10. Doerr-Stevens JK, Liu J, Stevens GJ, Kraner JC, Fontaine SM, Halpert JR, Sipes IG. Induction of cytochrome p-450 enzymes after repeated exposure to 4vinylcyclohexene in B6C3F1 mice. Drug Metab Disp. 1999;27:281-7.

11. Movassagh B, Soleiman-Beigi M. Stereo- and regioselective thiolysis of 1,2 epoxides in water. Synth Commun. 2007;37:3239-44. 
12. Ganesh V, Chandrasekaran S. One-pot synthesis of b-amino/b-hydroxy selenides and sulfides from aziridines and epoxides. Synthesis. 2009;19: 3267-78.

13. Springer LN, McAsey ME, Flaws JA, Tilly JL, Sipes IG, Hoyer PB. Involvement of apoptosis in 4-vinylcyclohexene diepoxide induced ovotoxicity in rats. Toxicol Appl Pharmacol. 1996;139:394-401.

14. Roosa KA, Mukai M, Place NJ. 4-Vinylcyclohexene diepoxide reduces fertility in female Siberian hamsters when treated during their reproductively active and quiescent states. Reprod Toxicol. 2015;51:40-6.

15. Abolaji AO, Adedara IA, Abajingin AO, Fatunmibi OJ, Ladipo EO, Farombi EO. Evidence of oxidative damage and reproductive dysfunction accompanying 4-vinylcyclohexene diepoxide exposure in female Wistar rats. Reprod Toxicol. 2016;66:10-9.

16. Abolaji AO, Toloyai PE, Odeleye TD, Akinduro S, Rocha JBT, Farombi EO. Hepatic and renal toxicological evaluations of an industrial ovotoxic chemical, 4-vinylcyclohexene diepoxide, in both sexes of Wistar rats. Environ Toxicol Pharmacol. 2016:45:28-40.

17. Kim SN, Jung YS, Kwon HJ, Seong JK, Granneman JG, Lee YH. Sex differences in sympathetic innervation and browning of white adipose tissue of mice. Biol Sex Differ. 2016. https:/doi.org/10.1186/s13293-016-0121-7.

18. Kalam A, Talegaonkar S, Vohora D. Differential profile of letrozole and exemestane on bone turnover markers in vinylcyclohexenediepoxide treated ovotoxic female mice. Fundam Clin Pharmacol. 2016;30:429-39.

19. Nirwane A, Majumdar A. Resveratrol and pterostilbene attenuated smokeless tobacco induced cardiovascular aberrations in estrogen deficient female rats. Toxicol Res. 2016:5:1604-18.

20. Clarkson TW. The toxicology of mercury. Crit Rev Clin Lab Sci. 1997;34(4): 369-403.

21. Clarkson TW. The three modern faces of mercury. Environ Health Persp. 2002:110:11-23.

22. Nogara PA, Farina M, Aschner M, Rocha JBT. Mercury in our food. Chem Res Toxicol. 2019. https://doi.org/10.1021/acs.chemrestox.9b00126.

23. Horowitz HM, Jacob DJ, Amos HM, Streets DG, Sunderland EM. Historical mercury releases from commercial products: global environmental implications. Environ Sci Technol. 2014;48:10242-50.

24. Baird C, Cann M, editors. Environmental Chemistry. New York: W.H. Freeman; 2004.

25. Burger J, Gochfeld M. Heavy metals in commercial fish in New Jersey. Environ Res. 2005;99:403-12.

26. Burger J, Elbin S. Metal levels in eggs of waterbirds in the New York harbor (USA): trophic relationships and possible risk to human consumers. J Toxicol Environ Health. 2014;78:78-91.

27. Burger J, Gochfeld M, Batang Z, Alikunhi N, Al-Jahdali R, Al-Jebreen D, Aziz MAM, Al-Suwailem A. Interspecific and locational differences in metal levels in edible fish tissue from Saudi Arabia. Environ Monit Assess. 2014;186:6721-46.

28. Burger J, Gochfeld M, Alikunhi N, Al-Jahdali H, Al-Jebreen D, Al-Suwailem A, Aziz MAM, Batang ZB. Human health risk from metals in fish from Saudi Arabia: consumption patterns for some species exceed allowable limits. Hum Ecol Risk Assess. 2015;21:799-827.

29. Gochfeld M, Burger J. Good fish/bad fish: A composite benefit-risk by dose curve. Neurotoxicology. 2005;26:511-20.

30. Burger J, Gochfeld M, Jeitner C, Donio M, Pittfield T. Sushi consumption rates and mercury levels in sushi: Ethnic and demographic differences in exposure. J Risk Res. 2014;17:981-97.

31. Clarkson TW, Vyas JB, Ballatori N. Mechanisms of mercury disposition in the body. Am J Ind Med. 2007:50:757-64.

32. Banerjee M, Karri R, Chalana A, Das R, Rai RK, Rawat KS, Pathak B, Roy G. Protection of endogenous thiols against methylmercury by benzimidazolebased thione by unusual ligand exchange reactions. Chem Eur J. 2017;23: 5696-707.

33. Branco V, Coppo L, Solá S, Lu J, Rodrigues CMP, Holmgren A, Carvalho C. Impaired cross-talk between the thioredoxin and glutathione systems is related to ASK-1 mediated apoptosis in neuronal cells exposed to Mercury. Redox Biol. 2017;13:278-87

34. Farina $M$, Aschner $M$, Rocha JBT. Oxidative stress in MeHg-induced neurotoxicity. Toxicol Appl Pharmacol. 2011;256:405-17.

35. Oliveira CS, Piccoli BC, Ashner M, Rocha JBT. Chemical speciation of selenium and mercury as determinant of their neurotoxicity. Adv Neurobiol. 2017;18:53-83.

36. Farina M, Aschner $M$, Rocha JBT. Mechanisms of methylmercury-induced neurotoxicity: Evidence from experimental studies. Life Sci. 2011;89:555-63.
37. Bridges CC, Zalups RK. Mechanisms involved in the transport of mercuric ions in target tissues. Arch Toxicol. 2016;91:63-81.

38. Vorojeikina D, Broberg K, Love TM, Davidson PW, Wijngaarden EV, Rand MD. Glutathione S-transferase activity moderates methylmercury toxicity during development in Drosophila. Toxicol Sci. 2017;157:211-21.

39. Bhattacharya P, Madden JA, Sen N, Hoyer PB, Keating AF. Glutathione Stransferase class mu regulation of apoptosis signal-regulating kinase 1 protein during VCD-induced ovotoxicity in neonatal rat ovaries. Toxicol Appl Pharmacol. 2013;267:49-56.

40. Keating AF, Sipes G, Hoyer PB. Expression of ovarian microsomal epoxide hydrolase and glutathione S-transferase during onset of VCD-induced ovotoxicity in B6C3F1 mice. Toxicol Appl Pharmacol. 2008;230:109-16.

41. Keating AF, Sen N, Sipes IG, Hoyer PB. Dual protective role for Glutathione S-transferase class pi against VCD-induced ovotoxicity in the rat ovary. Toxicol Appl Pharmacol. 2010;247:71-5.

42. Ahamed M, Posgai R, Gorey TJ, Nielsen M, Hussain SM, Rowe JJ. Silver nanoparticles induced heat shock protein 70, oxidative stress and apoptosis in Drosophila melanogaster. Toxicol Appl Pharmacol. 2010;242:263-9.

43. Abolaji AO, Kamdem JP, Lugokenski TH, Nascimento TK, Waczuk EP, Farombi EO, Loreto ÉL, Rocha JBT. Involvement of oxidative stress in 4vinylcyclohexene-induced toxicity in Drosophila melanogaster. Free Radic Biol Med. 2014;71:99-108.

44. Abolaji AO, Kamdem JP, Lugokenski TH, Farombi EO, Souza DO, da Silva Loreto ÉL, Roch JBT. Ovotoxicants 4-vinylcyclohexene 1,2-monoepoxide and 4-vinylcyclohexene diepoxide disrupt redox status and modify different electrophile sensitive target enzymes and genes in Drosophila melanogaster. Redox Biol. 2015;5:328-39.

45. Adedara IA, Abolaji AO, Rocha JBT, Farombi EO. Diphenyl diselenide protects against mortality, locomotor deficits and oxidative stress in Drosophila melanogaster model of manganese-induced neurotoxicity. Neurochem Res. 2016;41:1430-8.

46. Chauhan V, Chauhan A. Effects of methylmercury and alcohol exposure in Drosophila melanogaster: Potential risks in neurodevelopmental disorders. Int J Dev Neurosci. 2016;51:36-41.

47. Balinski MA, Woodruff RC. Differential sexual survival of Drosophila melanogaster on copper sulfate. Genetica. 2017;145:131-7.

48. Colak DA, Uysal H. Protective effects of coenzyme Q10 and resveratrol on oxidative stress induced by various dioxins on transheterozigot larvae of Drosophila melanogaster. Toxicol Res. 2017;6:521-5.

49. De Carvalho NR, Rodrigues NR, Macedo GE, Bristot IJ, Boligon AA, De Campos MM, Cunha FAB, Coutinho HD, Klamt F, Merritt TJS, Posser T, Franco JL. Eugenia uniflora leaf essential oil promotes mitochondrial dysfunction in Drosophila melanogaster through the inhibition of oxidative phosphorylation. Toxicol Res. 2017;6:526-34.

50. Figueira FH, Aguiar LMD, Rosa CED. Embryo-larval exposure to atrazine reduces viability and alters oxidative stress parameters in Drosophila melanogaster. Comp Biochem Physiol C Toxicol Pharmacol. 2017;191:78-85.

51. Nagpal I, Abraham SK. Ameliorative effects of gallic acid, quercetin and limonene on urethane-induced genotoxicity and oxidative stress in Drosophila melanogaster. Toxicol Mech Meth. 2017;27:286-92.

52. Peraza-Vega RI, Castañeda-Sortibrán AN, Valverde M, Rojas E, RodríguezArnaiz R. Assessing genotoxicity of diuron on Drosophila melanogaster by the wing-spot test and the wing imaginal disk comet assay. Toxicol Ind Health. 2017;33:443-53.

53. Reiter LT, Potocki L, Chien S, Gribskow M, Bier E. A systematic analysis of human disease-associated gene sequences in Drosophila melanogaster. Genome Res. 2001;11:1114-25.

54. Orr WC, Radyuk SN, Sohal RS. Involvement of redox state in the aging of Drosophila melanogaster. Antioxid Redox Signal. 2013;19:788-803.

55. Hirosawa-Takamori M, Jäckle H, Vorbrüggen $\mathrm{G}$. The class 2 selenophosphate synthetase gene of Drosophila contains a functional mammalian-type SECIS. EMBO Rep. 2000;1:441-6.

56. Castellano S, Morozova N, Morey M, Berry MJ, Serras F, Corominas M, Guigó $\mathrm{R}$. In silico identification of novel selenoproteins in the Drosophila melanogaster genome. Sci Rep. 2001;2:697-702.

57. Martin-Romero FJ, Kryukov GV, Lobanov AV, Carlson BA, Lee BJ, Gladyshev VN, Hatfield DL. Selenium metabolism in Drosophila: selenoproteins, selenoprotein mRNA expression, fertility, and mortality. J Biol Chem. 2001; 276(32):29798-804.

58. Robinson DN, Cooley L. Drosophila kelch is an oligomeric ring canal actin organizer. J Cell Biol. 1997;138(4):799-810. 
59. Whetten R, Organ E, Krasney P, Cox-Foster D, Cavener D. Molecular structure and transformation of the glucose dehydrogenase gene in Drosophila melanogaster. Genetics. 1988;120:475-84.

60. Adedara IA, Abolaji AO, Ladipo EO, Fatunmibi OJ, Abajingin AO, Farombi EO. 4-Vinylcyclohexene diepoxide disrupts sperm characteristics, endocrine balance and redox status in testes and epididymis of rats. Redox Rep. 2016. https://doi.org/10.1080/13510002.2016.1259718.

61. Oliveira VA, Favero G, Stacchiotti A, Giugno L, Buffoli B, Oliveira CS, Lavazza A, Albanese M, Rodella LF, Pereira ME, Rezzani R. Acute mercury exposition of virgin, pregnant, and lactating rats: histophatological kidney and liver evaluations. Environ Toxicol. 2016;32:1500-12.

62. Oliveira C, Joshee L, George H, Nijhara S, Bridges C. Oral exposure of pregnant rats to toxic doses of methylmercury alters fetal accumulation. Reprod Toxicol. 2017;69:265-75

63. Rasinger JD, Lundebye AK, Penglase SJ, Ellingsen S, Amlund $\mathrm{H}$. Methylmercury induced neurotoxicity and the influence of selenium in the brains of adult zebrafish (Danio rerio). Int J Mol Sci. 2017:18:725-39.

64. Bridges CC, Zalups RK. Transport of inorganic mercury and methylmercury in target tissues and organs. J Toxicol Environ Health B: Crit Rev. 2010;13:385-410.

65. Clarkson TW, Magos L. The toxicology of mercury and its chemical compounds. Crit Rev Toxicol. 2008:36:609-62.

66. George GN, Singh SP, Prince RC, Pickering IJ. Chemical forms of mercury and selenium in fish following digestion with simulated gastric fluid. Chem Res Toxicol. 2008;21(11):2106-10.

67. Harris HH. The chemical form of mercury in fish. Science. 2003;301:1203.

68. Xu Q, Zhao L, Wang Y, Xie Q, Yin D, Feng X, Wang D. Bioaccumulation characteristics of mercury in fish in the Three Gorges Reservoir. China Environ Pollut. 2018;243:115e126.

69. Pérez-Severiano F, Santamaría A, Pedraza-Chaverri J, Medina-Campos ON, Ríos C, Segovia J. Increased formation of reactive oxygen species, but no changes in glutathione peroxidase activity, in striata of mice transgenic for the Huntington's Disease mutation. Neurochem Res. 2004;29:729-33.

70. Habig WH, Pabst MJ, Jakoby WB. Glutathione S-transferases: the first enzymatic step in mercapturic acid formation. J Biol Chem. 1974;249:7130-40.

71. Ellman GL, Courtney KD, Andress JRV, Featherstone RM. A new and rapid colorimetric determination of acetylcholinesterase activity. Biochem Pharmacol. 1961;7:88-95.

72. Golombieski RM, Graichen DAS, Pivetta LA, Nogueira CW, Loreto ELS, Rocha JBT. Diphenyl diselenide [(PhSe)2] inhibits Drosophila melanogaster $\delta$ aminolevulinate dehydratase ( $\delta$-ALA-D) gene transcription and enzyme activity. Comp Biochem Physiol. 2008;147:198-204.

73. Livak KJ, Schmittgen TD. Analysis of relative gene expression data using real-time quantitative PCR. Methods. 2001;25:402-8.

74. Winterbourn CC, Hampton MB. Thiol chemistry and specificity in redox signaling. Free Radic Biol Med. 2008;45:549-61.

75. Schieber M, Chandel NS. ROS function in redox signaling and review oxidative stress. Curr Biol. 2014:24:453-62.

76. Davies KJA. Oxidative stress, antioxidant defenses, and damage removal, repair, and replacement systems. IUBMB Life. 2000:50:279-89.

77. Rudgalvyte M, VanDuyn N, Aarnio V, Heikkinen L, Peltonen J, Lakso M, Nass R, Wong G. Methylmercury exposure increases lipocalin related (lpr) and decreases activated in blocked unfolded protein response (abu) genes and specific miRNAs in Caenorhabditis elegans. Toxicol Lett. 2013:222:189-96.

78. Mailloux RJ, Yumvihoze E, Chan HM. Superoxide produced in the matrix of mitochondria enhances methylmercury toxicity in human neuroblastoma cells. Toxicol Appl Pharmacol. 2015;289:371-80.

79. Yang T, Xu Z, Liu W, Feng S, Li H, Guo M, Deng Y, Xu B. Alpha-lipoic acid reduces methylmercury-induced neuronal injury in rat cerebral cortex via antioxidation pathways. Environ Toxicol. 2017;32:931-43.

80. Feng S, Xu Z, Wang F, Yang T, Liu W, Deng Y, Xu B. Sulforaphane prevents methylmercury-induced oxidative damage and excitotoxicity through activation of the Nrf2-ARE pathway. Mol Neurobiol. 2017:54:375-91.

81. Lee K, Raisuddin S, Rhee J, Hwang D, Yu IT, Lee Y, Park HG, Lee J. Expression of glutathione S-transferase (GST) genes in the marine copepod Tigriopus japonicas exposed to trace metals. Aquat Toxicol. 2008;89:158-66.

82. Carvalho-Neta RNF, Abreu-Silva AL. Glutathione S-Transferase as biomarker in Sciades herzbergii (Siluriformes: ariidae) for environmental monitoring: the case study of São Marcos Bay, Maranhão. Brazil. Lat Am J Res. 2013;41:217-25.

83. Liu H, He J, Zhao R, Chi C, Bao Y. A novel biomarker for marine environmental pollution of pi-class glutathione S-transferase from Mytilus coruscus. Ecotox Environ Saf. 2015;118:47-54.
84. Hayes JD, Pulford DJ. The glutathione S-transferase supergene family: regulation of GST and the contribution of the isoenzymes to cancer chemoprotection and drug resistance part II. Crit Rev Biochem Mol Biol. 1995:30:521-600.

85. Hayes JD, Flanagan JU, Jowsey IR. Glutathione transferases. Annu Rev Pharmacol Toxicol. 2005:45:51-88.

86. Sheehan D, Meade G, Foley VM, Dowd CA. Structure, function and evolution of glutathione transferases: implications for classification of non-mammalian members of an ancient enzyme superfamily. Biochem J. 2001;360:1-16.

87. Board PG, Menon D. Glutathione transferases, regulators of cellular metabolism and physiology. Biochim Biophys Acta Gen Subj. 2013;1830: 3267-88.

88. Sánchez-Gómez FJ, Díez-Dacal B, García-Martín E, Agúndez JA, Pajares MA Pérez-Sala D. Detoxifying enzymes at the cross-roads of inflammation, oxidative stress, and drug hypersensitivity: role of glutathione transferase p1-1 and aldose reductase. Front Pharmacol. 2016;7:237.

89. Zemolin APP, Meinerz DF, de Paula MT, Mariano DOC, Rocha JBT, Pereira AB, Posser T, Franco JL. Evidences for a role of glutathione peroxidase 4 (GPX4) in methylmercury induced neurotoxicity in vivo. Toxicology. 2012;302:60-7.

90. Adedara IA, Rosemberg DB, Souza DO, Kamdem JP, Farombi EO, Aschner M, Rocha JBT. Biochemical and behavioral deficits in the lobster cockroach Nauphoeta cinerea model of methylmercury exposure. Toxicol Res. 2015:4:442-51.

91. Maulvault AL, Barbosa V, Alves R, Custódio A, Anacleto P, Repolho T, Ferreira PP, Rosa R, Marques A, Diniz M. Ecophysiological responses of juvenile seabass (Dicentrarchus labrax) exposed to increased temperature and dietary methylmercury. Sci Total Environ. 2017;586:551-8

92. da Silva AP, Meotti FC, Santos AR, Farina M. Lactational exposure to malathion inhibits brain acetylcholinesterase in mice. Neurotoxicology. 2006; 27:1101-5.

93. Moraes-Silva L, Siqueira LF, Oliveira VA, Oliveira CS, Ineu RP, Pedroso TF, Fonseca MM, Pereira ME. Preventive effect of $\mathrm{CuCl}_{2}$ on behavioral alterations and mercury accumulation in central nervous system induced by $\mathrm{HgCl}_{2}$ in newborn rats. J Biochem Mol Toxicol. 2014:28:328-35.

94. Kwiatkowska M, Nowacka-Krukowska H, Bukowska B. The effect of glyphosate, its metabolites and impurities on erythrocyte acetylcholinesterase activity. Environ Toxicol Pharmacol. 2014;37:1101-8.

95. Kim YH, Kwon DH, Ahn HM, Koh YH, Lee SH. Induction of soluble AChE expression via alternative splicing by chemical stress in Drosophila melanogaster. Insect Biochem Mol Biol. 2014;48:75-82.

96. Wootten V, Brown DR, Callahan BG, Vetrano K, Wadman P, Melia J, Mulligan T, Schatz RA. Behavioral and biochemical alterations following in utero exposure to methylmercury. Neurobehav Toxicol Teratol. 1985;7:767-73.

97. Piccoli BC, Alvim JC, da Silva FD, Nogara PA, Olagoke OC, Aschner M, Oliveira CS, Rocha JBT. High level of methylmercury exposure causes persisted toxicity in Nauphoeta cinerea. Environ Sci Pollut Res. 2019.

98. Han J, Yang X, Chen X, Li Z, Fang M, Bai B, Tan D. Hydrogen sulfide may attenuate methylmercury-induced neurotoxicity via mitochondrial preservation. Chem Biol Interact. 2017:1:66-73.

99. Dinkova-Kostova AT, Holtzclaw WD, Cole RN, Itoh K, Wakabayashi N, Katoh Y, Yamamoto M, Talalay P. Direct evidence that sulfhydryl groups of Keap1 are the sensors regulating induction of phase 2 enzymes that protect against carcinogens and oxidants. Proc Natl Acad Sci USA. 2002;99:11908-13.

100. Zhang H, Davies KJA, Forman HJ. Oxidative stress response and Nrf2 signaling in aging. Free Radic Biol Med. 2015;88:314-36.

101. Pitoniak A, Bohmann D. Mechanisms and functions of Nrf2 signaling in Drosophila. Free Radic Biol Med. 2015;88:302-13.

102. Chatterjee N, Tian M, Spirohn K, Boutros M, Bohmann D. Keap1independent regulation of Nrf2 activity by protein acetylation and a BET bromodomain protein. PLoS Genet. 2016;12:1-20.

103. Sykiotis GP, Bohmann D. Keap1/Nrf2 signaling regulates oxidative stress tolerance and lifespan in Drosophila. Dev Cell. 2008;14:76-85.

104. Misra JR, Horner MA, Lam G, Thummel CS. Transcriptional regulation of xenobiotic detoxification in Drosophila. Gene Dev. 2011:25:1796-806.

105. Deng H. Multiple roles of Nrf2-Keap1 signaling. Fly. 2014;8:7-12

106. Unoki T, Akiyama M, Kumagai Y, Gonçalves FM, Farina M, da Rocha JBT, Aschner M. Molecular pathways associated with methylmercury-induced Nrf2 modulation. Front Genet. 2018;9:373.

107. Antunes Dos Santos A, Ferrer B, Marques Gonçalves F, Tsatsakis AM, Renieri EA, Skalny AV, Farina M, Rocha JBT, Aschner M. Oxidative stress in methylmercury induced cell toxicity. Toxics. 2018;6(3):47. 
108. Lovato FL, Rocha JBT, Dalla Corte CL. Diphenyl diselenide protects against methylmercury-induced toxicity in Saccharomyces cerevisiae via the Yap1 transcription factor. Chem Res Toxicol. 2017;30(5):1134-44.

109. Lee W, Choi KS, Riddell J, Ip C, Ghosh D, Park JH, Park YM. Human peroxiredoxin 1 and 2 are not duplicate proteins: The unique presence of Cys83 in Prx 1 underscores the structural and functional differences between Prx1 and Prx2. J Biol Chem. 2007;282:22011-22.

110. Nordberg J, Arnér ESJ. Reactive oxygen species, antioxidants, and the mammalian thioredoxin system. Free Rad Biol Med. 2001;31:1287-312.

111. Karin $\mathrm{M}$, Ben-Neriah Y. Phosphorylation meets ubiquitination: The control of NF-k $\beta$ activity. Annu Rev Immunol. 2000;18:621-63.

112. Ghosh S, May MJ, Kopp EB. NF-Kß and Rel proteins: evolutionarily conserved mediators of immune responses. Annu Rev Immunol. 1998;16:225-60.

113. Chen D, Li Z, Yang Q, Zhang J, Zhai Z, Shua H-B. Identification of a nuclear protein that promotes NF-KB activation. Biochem Biophys Res Comm. 2003; 310:720-4.

114. Niehoff A, Bauer OB, Kröger S, Fingerhut S, Schulz J, Meyer S, Sperling M, Jeibmann A, Schwerdtle T, Karst U. Quantitative bioimaging to investigate the uptake of mercury species in Drosophila melanogaster. Anal Chem. 2015; 87:10392-6

\section{Publisher's Note}

Springer Nature remains neutral with regard to jurisdictional claims in published maps and institutional affiliations.

Ready to submit your research? Choose BMC and benefit from:

- fast, convenient online submission

- thorough peer review by experienced researchers in your field

- rapid publication on acceptance

- support for research data, including large and complex data types

- gold Open Access which fosters wider collaboration and increased citations

- maximum visibility for your research: over $100 \mathrm{M}$ website views per year

At $\mathrm{BMC}$, research is always in progress.

Learn more biomedcentral.com/submissions 